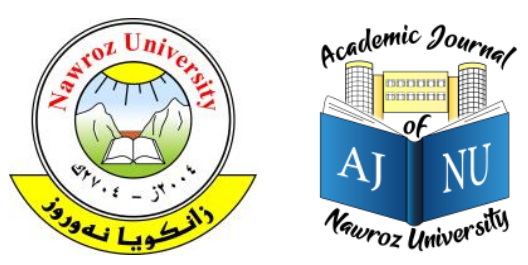

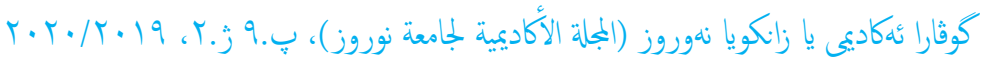

حقوق الطبع والنشر ؟2017. هذه مقالة الوصول اليها مفتوح موزعة تحت رخصة

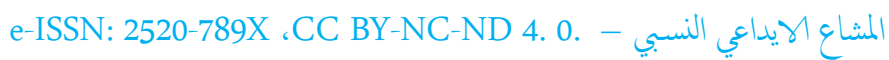

https://doi.org/10.25007/ajnu.v9n2a705

\title{
أثر الاختصاص القضائي الدولي في تحديد القانون الواجب الثطبيق على العلاقات الخاصة الدولية "دراسة تخليلية"
}

د. عبدالله فاضل حامد، كلية القانون والعلوم السياسية، جامعة دهوك، كردستان العراق

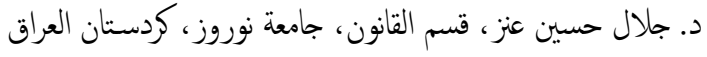

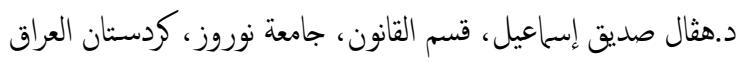

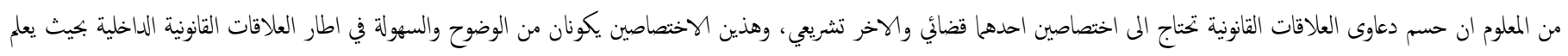

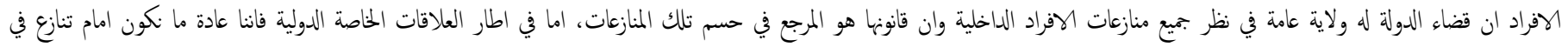

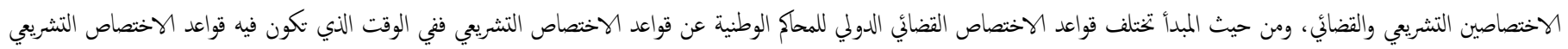

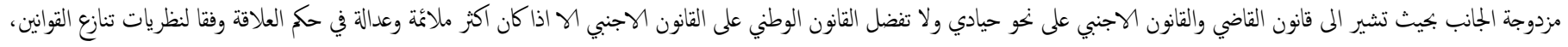

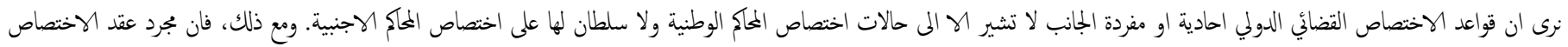

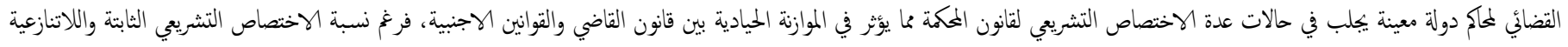

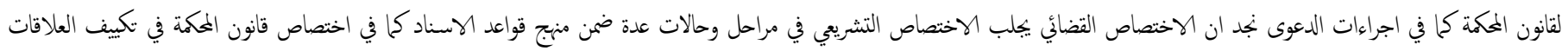

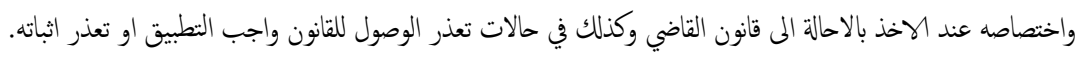

الدولية يناثر في اكثر من مرحلة وحالة من مراحل وحالات تحديد القانون واجب التطبيق بالاختصاص القضائي كما في مرحلة التكييف والاحالة وحالة استبعاد القانون الاجنبي وتعذر اثباته فكأن العلاقة وطيدة بين الاختصاصين بمعنى كلما اختصت المحاك الوطنية في نظر الدعاوى المشوبة بعنصر اجنبي كلما تغلبت كفة قانون المحكة في السريان على تلك العلاقات المنظورة دعاواها اهام المحاك الوطنية وكل ذلك على حساب القوانين الاجنية. عليه، يتناول هذا البحث بيان اثر الاختصاص القضائي الدولي للمحاك؟ الوطنية في تحديد القانون واجب التطبيق على العلاقات الخاصة

$$
\text { الدولية. }
$$

2.1

تمتاز قواعد تنازع القوانين بعدة خصائص لعل من اهما هو انها قواعد محايدة تشير الى القانون الواجب التطبيق حسب ضابط الاسناد الكلمن فيها على اساس ان ذلك القانون هو قانون بيئة العلاقة محل النزاع لذلك فهو انسب القوانين واكثرها ملائمة في حكم العلاقة سواءكان قانون المحكمة التي تنظر النزاع او قانونا اجنبيا، ومع ذلك فان

\section{1. مقدمة}

$$
\text { يحسن بنا ان نقدم للموضوع وفق الفقرات الآتية: }
$$

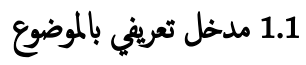

تثير العلاقات الخاصة الدولية التي تتضمن عنصرا اجنبيا او اكثر تنازعا مزدوجا، احدها يكون بشأن الاختصاص القضائي الدولي للمحاك الوطنية والذي تتناول قواعده حالات اختصاص المحاك الوطنية في النظر في الدعاوى المشوبة بعنصر اجنبي كما لو رفع زوجان اجنبيان دعوى طلاق او ننقة امام المحاك العراقية فيكون السؤال هل تختص المحكى العراقية بالنظر في هكذا دعوى ام لا؟، اما التنازع الثاني فهو تنازع الاختصاص التشريعي من حيث المكان او ما يعرف بتننازع القوانين، وتتناول قواعده تحديد القانون واجب التطبيق على العلاقات المشوبة بعنصر اجنبي كما لو طلب تحديد القانون واجب النطبيق على العقد الدولي والذي قد يكون قانون المحكة المرفوع اماها النزاع وقد يكون قانونا اجنبيا حسب ما تقضي به قواعد تنازع القوانين الوطنية. وعادة ما يستتبع الاختصاص القضائي الدولي للمحاك الوطنية اعحال قواعد تنازع القوانين في قانون المحكة وهو ما يعني ان تحديد القانون واجب التطبيق على العلاقات الخاصة 


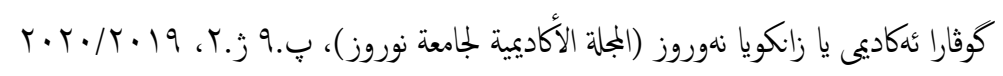

وعملية ترى ان القاضي يميل عادة الى عقد الاختصاص لقانونه الوطني اي قانون المكمة بعد ما عقد لها الاختصاص القضائي فكأن الاختصاص القضائي يتعبه غالبا الاختصاص التشريعي ايضا خلافا لما تقضي به قاعدة الاسناد المحايدة والمزدوجة، عليه فان مشكلة البحث تتمثل في الميل النفسي والاعتبارات العملية التي تقف خلف الحاق الاختصاص التشريعي بالاختصاص القضائي وهو ما يخالف اهم مبادئ نظرية تنازع القوانين والتي من بينها اعطاء الاختصاص للقانون الوكثر صلة بالعلاقة محل النزاع والذي يمثل في الوقت ذاته قانون بيئة تلك العلاقة لذلك فهو الانسب في حكم

العلاقة.

\section{1}

سنتبع في كتاية هذا البحث المنهج التحليلي من خلال تحليل قواعد تنازع القوانين العراقية وتشخيص الحالات التي يتلازم فيها الاختصاص التشريعي بالاختصاص القضائي اضافة الى الوقوف على الاراء الفقهية في هذا الشأن.

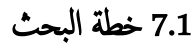

سنوزع هيكل البحث على ثلاثة مباحث، سنتناول في المبحث الاول تعريف الاختصاص القضائي الدولي وعلاقته بالاختصاص التشريعي، وفي المبحث الثاني سندرس فيه أثر الاختصاص القضائي الدولي في تحديد القانون واجب التطبيق في مرحلتي التكيف والاحالة، اما المبحث الثالث والاخير فسنخصصه لبيان اثر الاختصاص القضائي الدولي في تحديد القانون واجب التطبيق في حاتي استبعاد

$$
\text { القانون الاجنبي وتعذر الوصول اليه. }
$$

\section{2. المبحث الأول: تعريف الاختصاص القضائي الدولي وعلاقته بالاختصاص التشريعي}

ان التنازع من حيث المكان لا يقتصر على الاختصاص التشريعي وانما يشمل تنازع الاختصاص القضائي ايضا، وينصب جوهر هذا التنازع على معرفة الحالات التي تختص فيها المحاك الوطنية في نظر الدعاوى التي يكون فيها عنصرا اجنبيا سواءكان من ناحية اطراف الدعوى او من ناحية العناصر الاخرى في العلاقة محل الدعوى كمحل وجود المال او محل حدوث الواقعة المنشئة للالتزام او محل تنفيذ الالتزام، والغالب ان انعقاد الاختصاص القضائي للنظر في الدعاوى المشوبة بعنصر اجنبي يتبعه عقد الاختصاص التشريعي للقانون الوطني اي قانون المحكة ذاتها التي تنظر في الدعوى. عليه، يلزم علينا، قبل اظهار العلاقة بين الاختصاص القضائي الدولي للمحاكَ الوطنية والاختصاص التشريعي، ان نعرض بالثرح والايضاح لمفهوم الاختصاص القضائي
مجرد اختصاص المحاك الوطنية في نظر النزاع يؤدي الى اختصاص قواعد تنازع القوانين الوطنية لتلكك المحكمة وعليه فان القانون واجب التطبيق سيتم تحديده وفق تصورات المشرع الوطني للقانون الانسب والكثر ملائمة في حكم العلاقة وكثيرا ما يرى المشرع ان قانونه الوطني افضل من القوانين الاجنية اضافة الى ان مراحل عدة من مراحل تحديد القانون واجب التطبيق تستعين المحكة بالقانون الوطني في سبيل الوصول الى القانون واجب التطبيق كما في مرحلة تكييف العلاقة حيث عادة ما يكون التكييف حسب قانون المحكة، ويجب ان لا ننسى ان لقانون المحكمة دورا احتيطيا في منهج قاعدة الاسناد بجيث يعطى له الاختصاص كلما تعذر الوصول الى القانون واجب التطبيق. عليه، فان للبحث في هذا الموضوع اهمية نظرية ثكن في فص منهج قاعدة الاسناد لاجل الوقوف على الحالات التي يثأثز فيها الاختصاص التشريعي بالاختصاص القضائي الدولي للمحاكم الوطنية، كما ان للبحث اهمية عملية تتمثل في تنبيه القضاء ورجال القانون على ضرورة المحافظة على حيادية قاعدة تنازع القوانين والتقليل من حالات اللجوء المى تطبيق قانون المحكة على العلاقات الخاصة الدولية.

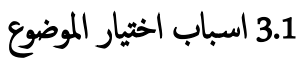
ثمن اسباب اختيار الموضوع في تقصي الحالات التي يؤثر الاختصاص القضائي الدولي للمحاك؟ الوطنية في عقد الاختصاص لقانون المحكة التي تنظر في الدعوى المشوبة بعنصر اجنبي على اعتبار ان هذا الموضوع لم يسلط عليه الضوء الكلفي من قبل فقه القانون الدولي الخاص، والسبب الاخر يكمن في محولة اثبات العلاقة الوطيدة بين الاختصاصين القضائي والتشريعي بشأن العلاقات الخاصة الدولية.

4.1

يفتر البحث وجود علاقة وطيدة بين الاختصاصين القضائي والتشريعي بشأن العلاقات الخاصة الدولية على نخو كلما عقد الاختصاص للمحاك الوطنية لدولة ماكلما زادة حالات اختصاص القانون الوطني لتلك المحاك، كما يفتض البحث ضرورة المحافظة على ما تقضي به قاعدة الاسناد الوطنية بشأن القانون واجب التطبيق وعدم اهمال ذلك عبر اعطاء الاختصاص لقانون المكمة.

\section{1}

عادة ما تتضمن قاعدة الاسناد الوطنية ضابط اسناد محايد يشير الى القانون واجب التطبيق دون العلم المسبق بمضمون ذلك القانون والني قد يكون قانون المحكة ذاتها التي تنظر في الدعوى وقد يكون قانونا اجنبيا، ولكن بناء على اعتبارات نفسية 


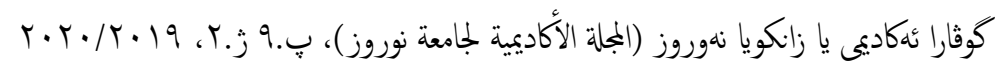

اي اشارة لتنازع الاختصاص القضائي(4). ولاحقا عندما ظهرت نظرية تنازع القوانين فان تلك المبادئ القديمة للاختصاص القضائي اثرت بقوة على تحديد القانون واجب التطبيق على العلاقات الخاصة ذات البعد الدولي. وفي القانون العراقي، ادرج المثرع نصوص تنازع الاختصاص القضائي في القانون المدني تحت مسمى (التنازع من حيث المكان) وقصد في الفقرة (أ) تنظيم (الننازع الدولي من حيث الاختصاص القضائي)(5)، فشمل هذا التنظيم قواعد قانونية تحدد للمحكمة العراقية اختصاصها القضائي الدولي، بعبارة اخرى، تحدد حالات اختصاص المحكمة العراقية للنظر في الدعاوى التي يشوبها عنصرا اجنبيا. ويفهم من ذلك، ان قواعد تنازع الاخصاص القضائي الدولي هي قواعد وطنية تتناول اختصاص المحاك الوطنية حصرا ولا سلطان لها على اختصاص المحكي الاجنية، او انها تلك القواعد التي تبيّن الاحوال التي تتتص فهيا المحاك الوطنية بنظر النزاع المشتمل على عنصر اجنبي وهي قواعد خاصة بكل دولة(6)، ولاجل ذلك توصف قواعد الاختصاص القضائي الدولي بانها مفردة الجانب وظيفتها تحديد اختصاصات المحكي الوطنية دون المحاكي الاجنبية، وهذه الصفة تعد علامة فارقة تمزّها عن قواعد الاختصاص التشريعي التي تعد مزدوجة تشير الى اختصاص القانون الوطني كما تشير في الوقت ذاته الى اختصاص القانون الاجنبي (7). والفرق في ذلك يكمن في الشخص الخخاطب بأمر قاعدة الاختصاص في الحالتين، فنتى تكون قاعدة تنازع الاختصاص القضائي مزدوجة يجب ان يتعدى الامر شخص القاضي الوطني الى شخص القاضي الاجنبي على نحو يقول المشرع العراقي احيانا ان الاختصاص لك اهيا القاضي الاجنبي وهذا غنر منكن لانه لا سلطان للمشرع العراقي على القاضي الاجنبي كما ان لا سلطان لمشرع اجنبي على القاضي العراقي، اما امر قاعدة تنازع القوانين فانه يكون موبحا للقاضي الوطني سواء كان القانون واجب التطبيق هو قانون القاضي ذاته او كان قانونا اجنبيا، فالامر في هذه الحالة يكون على هذا النحو: ان الاختصاص لقانونك الوطني اهيا القاضي العراقي او ان الاختصاص للقانون الفرنسي اهها القاضي العراقي، لذلك تم قبول ميزة الازدواجية في قاعدة تنازع القوانين دون قاعدة تنازع الاختصاص القضائي التي لا يمكن ان تكون اله مفردة او

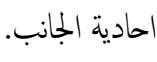
2.2 المطلب الثاني: ضوابط الوختصاص القضائي الدولي للمحاكم الوطنية ذكزنا انفا، ان قاعدة الاختصاص القضائي الدولي للمحاكَ الوطنية هي قاعدة مفردة الجانب تشير الى حالات اختصاص المحاك الوطنية للنظر في المنازعات التي تثيرها
الدولي والمعايير المعتمدة في تحديد الاختصاص القضائي الدولي للمحاكم الوطنية وهو ما سنتناوله في ثلاثة مطالب.

1.2 المطلب الأول: تعريف الاختصاص القضائي الدولي للمحاكم الوطنية وطبيعة قواعده لعله كان من الطبيعي ان ينظر في دعاوى العلاقات الخاصة الدولية محاك ذات طبيعة دولية على نخو يحصل الانسجام التام بين طبيعة الدعوى التي تكون عابرة للحدود الدولية والمكمة الختصة بالفصل في منازعات تالك الدعاوى، لا ان يتم النظر في دعاوى ذات صفة دولية من قبل محاكم وطنية وجدت في الاصل للنظر في المنازعات الناشئة

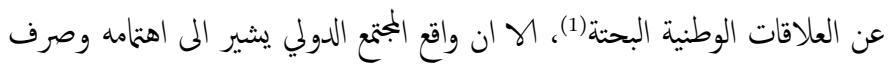
جهوده في سبيل اتاحة محاكم دولية للنظر في منازعات القانون الدولي العام، اما المنازعات التي تثيرها علاقات القانون الدولي الخاص فلا زالت خاضعة في الاساس لاختصاص المحاك الوطنية باستثناء مراكز التحكيم الدولية والتي يكن اعتبارها قضاء دوليا بالمعنى الصحيح كمته الفصل في منازعات العلاقات الخاصة الدولية(2)، ولماكان الاختصاص للمحاكُ الوطنية فان القاضي غالبا ما يميل نسيا نحو تطبيق قانونه الوطني اضافة الى انحياز المشرع في قواعد تنازع القوانين الى ترجيح قانونه الوطني كثيرا وهذا كله يبرز اثر الاختصاص القضائي في تحديد القانون واجب التطبيق على العلاقات الخاصة الدولية. ومن الناحية التاريخية، فان تنازع الاختصاص القضائي يعد قديما مقارنة بتنازع الاختصاص التشريعي، فالمعلوم في فقه القانون الدولي الخاص ان نظرية تنازع القوانين ظهرت في القرن الثاني عشر في شال ايطاليا وحينذاك كانت تعالج فروضا متعلقة بتنازع داخلي بين قوانين مدن ، ولم يؤسس لامكانية تطبيق قانون اجنبي الا في القرن السابع عشر عندما ذهب القضاء والفقه الهولندي الى امكنية تطبيق قانون اجنبي امام المحاك الهولندية على اساس مبدأ المجاملة الدولية(3)، بينا كان تأسيس اختصاص المحاكي الوطنية للنظر في دعاوى الاجانب او التي فها عنصرا اجنيا قائما على الاختصاص الوقلي والشخصي والاخيران هـا مبدأن قديمان يعطيان الاختصاص للمحاك الوطنية للنظر في دعاوى كل المقمين في ارض الدولة وكل الدعاوى الناشئة عن الوقائع القانونية التي تحدث فيها بغض النظر عن جنسية الاطراف اضافة الى الاختصاص القائم على تبعية احد اطراف الدعوى لدولة القاضي وبغض النظر عن مكان حدوث الواقعة التي اثارت الدعوى القضائية، واستنادا المى ذلك فان تنازع الاختصاص القضائي لم يكن محل اهتمام من قبل فقه القانون الدولي الخاص القديم حيث لا تجد في المؤلفات القديمة 


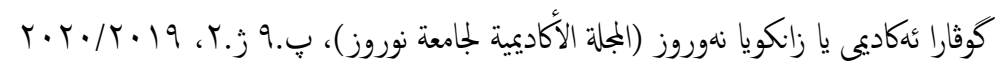

المتقاضيان والتي قد تكون صريحة اذا ما اختارا التقاضي امام المحاك العراقية للنظر في منازعته، او قد تكون ضمنة كما في حالة رفع الدعوى امام المحاكم العراقية من قبل المدعي رغز عدم وجود ضابط يؤكد اختصاصها ومع ذلك يسكت المدعى عليه ولا يدفح بعدم اختصاص القضاء العراقي(14)، علما ان القانون العراقي لم ينص على حالة الخضوع الارادي كضابط من ضوابط الاختصاص القضائي الدولي للمحاكم العراقية(15)، ورغز ذلك فاننا نتقد انه يمكن الاخذ بها الضابط في بناء الاختصاص للقضاء العراقي لاسيا كيفنا قواعد الاختصاص القضائي الدولي للمحاكم بانها قواعد لا تتعلق بالنظام العام اولا(16)، وثانيا ان الاخذ بهذا الضابط يؤدي الى توسيع اختصاص القضاء العراقي وهو امر محمود تسعى كل دولة المى تحقيقه بشرط توفر درجة الارتباط المبررة للاختصاص. ويجدر بالذكر، ان اختيار المتقاضيان قضاء دولة معينة للنظر في المنازعات التي تنشأ عن العلاقات التي تربطهم انما يعد قرينة على اختيار قانون تلك الدولة ايضا لحكم العلاقة لاسيا العلاقات التعاقدية، ونقصد على وجه التحديد ان الاختصاص القضائي لمحاك دولة معينة بناء على ارادة الاطراف قاد الى اختصاص تشريع تلك الدولة في حكى المنازعة(17). وبنى المشرع العراقي الاختصاص القضائي الدولي للمحاكم العراقية على المعيار الشخصي والمتمثل في جنسية المدعى عليه، فذهبت المادة (14) من القانون المدني العراقي المى انه ((يقاضي العراقي امام محاك العراق عما ترتب في ذمته من حقوق حتى ما نشأ منها في الخارج))، فالجنسية العراقية التي يحملها المدعى عليه تككي في اعطاء الاختصاص للمحاك العراقية حتى اذاكان الحق محل المنازعة قد نشأ في الخارج، ونرى ان بناء الاختصاص القضائي الدولي على معيار شخصي متمثل في جنسية المدعى عليه اصبح معيارا قديما ولم يعد معبرا عن درجة الارتباط الوثيق بين المحكة والدعوى على لي لئل نخو يبرر اختصاص الاولى في نظر الثانية، فالاولى هو التخلى عن هذا المعيار في بناء

الاختصاص القضائي الدولي وهو ما ذهبت اليه تشريعات حديثة في عدة دول (18).

3.2 المطلب الثالث: علاقة الاختصاص القضائي الدولي بالاختصاص التشريعي من حيث المبدأ، يستقل في القانون الدولي الخاص الاختصاصين القضائي والتشريعي كل منها عن الاخر (19)، فلكل قواعده الخاصة به والمحددة للاختصاص وفق ضوابط معينة، اضافة الى وجود فاصل زمني بين الاختصاصين على نو يسبق الاختصاص القضائي الاختصاص التشريعي وهو ما يلزم قيام المحكة بالبت في اختصاصها اولا ومن ثم البحث عن القانون واجب التطبيق. ولا شك، ان وجود الاختصاصين معا تفرضها
العلاقات الخاصة الدولية، وعادة ما يبنى الاختصاص على ضوابط شبيه الى حد ما بتلك الضوابط المعتمدة في تحديد الاختصاص المكاني للمحاكم الوطنية لاجل النظر في المنازعات التي يثرها القانون الداخلي(8)، وهذه الضوابط انما تعبر عادة عن درجة من الارتباط الوثيق بين المككة والدعوى المنظورة اماها اضافة المى اعتبارات عملية واخرى متعلقة بالتيسير على المدعى عليه(9). فضابط محل وجود العقار يعطي الاختصاص للمحكمة سواء كنا امام اختصاص قضائي مكاني داخلي للمحاكُ او كنا امام اختصاص قضائي دولي للمحاك؟ الوطنية، ومصداقا وتأكيداً على ذلك نصت المادة (15/ب) من القانون المدني العراقي على ان الاجنبي يمكن مقاضاته امام محاكي العراق (اذا كانت المقاضاة في حق متعلق بعقار موجود في العراق او بمنقول موجود فيه وقت رفع الدعوى)(10)، كما ان موطن او محل اقامة المدعى عليه يعد ضابطا للاختصاص القضائي المكاني في القانون الداخلي متى ماكان محل الدعوى مالا منقولا(11)، والضابط الاخير يعد في الوقت ذاته محددا للاختصاص القضائي الدولي للمحاكئ الوطنية، وعلى ذلك نصت المادة (15/15) من القانون المدني العراقي اذ يقاضي الاجنبي امام المحاك العراقية ((اذا وجد في العراق))، وهنا اكتنى المشرع العراقي بكجرد وجود الاجنبي في العراقي دون اشتراط توطنه او اقامته المعتادة في العراق، ونعتقد انه ليس من الصواب تأسيس اختصاص المحاكم العراقية للنظر في الدعوى المقامة على الاجنبي على مجرد وجوده في العراق اذ قد يكون ذلك الوجود عرضيا لا يتعدى ايام او حتى ساعات، علما ان المبدأ في تأسيس الاختصاص القضائي الدولي للمحاك الوطنية هو وجود درجة من الارتباط الوثيق بين المحكة والدعوى المنظورة امامها على نحو يبر الاختصاص وجردد وجود المدعى عليه الاجنبي في العراق لا يعبر عن درجة الارتباط تلك(12)، فكان الاولى بالشرع العراقي اشتراط محل اقامة الاجنبي في العراق على اقل تقدير. وقد بنى المشرع العراقي الاختصاص القضائي الدولي للمحاكم العراقية على ضوابط مكانية اخرى متعلقة بالعلاقات القانونية ذاتها دون النظر الى جنسية الاطراف او محل تواجدهم، وعلى وجه الخصوص العلاقات التي ينشأ عنها التزامات مالية او ان خرق الالتزام ينشأ عنه عادة تعويض مادي ولا فرق هنا بين انواع الالتزامات اي سواء كانت تعاقدية او غير تعاقدية، وعلى ذلك جاءت المادة (15/ج) لتؤكد اختصاص المحاكَ العراقية في مقاضاة الاجنبي متى ماكان ((..موضوع التقاضي عقداً تم ابرامه في العراق او كان واجب التنفيذ فيه او كان التقاضي عن حادثة وقعت في العراق))(13). ويككن بناء الاختصاص القضائي الدولي للمحاكي العراقية ايضا على ارادة 


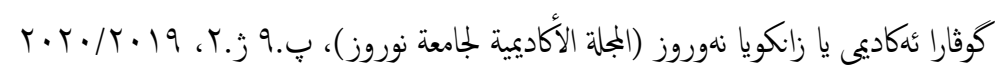

وجرد الاموال ووضع الاختام وتعيين حارس عليها وبيع ما هو سريع التلف منها...الخ)(24). ومن ناحية ثانية، فان القواعد القانونية التي استعان بها القاضي في تحديد القانون الاجنبي واجب التطبيق انما هي قواعد تنازع القوانين في التشريع الوطني لدولة القاضي، فالذي قدر ملائمة القانون الاجنبي للعلاقة محل النزاع هو المشرع الوطني في دولة القاضي وليس المشرع الذي وضع القانون الاجنبي واجب التطبيق، وقد يحدث ان تعطي قواعد التنازع الوطنية الاختصاص لقانون اجنبي رغا عن ارادة مشرعه كما لو اعطي الاختصاص للقانون الانكليزي لتنظيم علاقة شخص بريطاني متوطن في الهند على اساس ضابط الجنسية علما ان القانون واجب التطبيق حسب قواعد الاختصاص التشريعي الهمكيزية هو القانون الهندي باعتباره قانون موطن ذلك الشخص، ولا يكن استشارة قواعد تنازع القوانين الاجنية الا في حالة الاخذ بنظرية الاحالة والتي ترفضها معظم القوانين ومنها القانون العراقي كمبدأ(25). ويفهم من هذا، ان الذي قدر ملائمة سريان القانون الاجنبي هو المشرع الوطني عبر قواعد اسناد وطنية، واذا كان صحيحا ان فوى قواعد الاسناد تتشابه على المستوى الدولي نظرا للاصل النظري المشترك لها(26)، اله ان المثرع الوطني عادة ما يقوم بصياغة قاعدة الاسناد على نحو تنحرف عن اصولها النظرية كلما استدعت مصلحة الدولة ذلك.

3. المبحث الثاني: اثر الاختصاص القضائي الدولي في تحديد القانون واجب الثطبيق

\section{في مرحلتي التكييف والاحالة}

يوصف منهج قاعدة الاسناد بانه منهج معقد وكثير الاليات والمراحل التي ينبني مراعانها في سبيل الوصول الى القنون واجب التطبيق ومن ثخ حسم المنازعة وفق احكمه، ومن بين تلك المراحل مرحلة النكييف والاحالة، واذا ما انعمنا النظر في كلتا المرحلتين سنجد فيها ثاثيرا واضحا للاختصاص القضائي على الاختصاص التشريعي، ولاجل الاحطة بما ذك سنقسم هذا المبحث المى مطلبين، سنتناول في الاول منها اثر الاختصاص القضائي الدولي في مرحلة تكييف العلاقات الخاصة الدولية، وفي المطلب الثاني سندرس اثر الاختصاص القضائي الدولي في مرحلة الاخذ بالاحالة. 1.3 المطلب الاول: اثر الاختصاص القضائي الدولي في مرحلة تكييف العلاقات

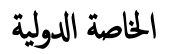

يُشبهِ فقه القانون الدولي الخاص قواعد الاسناد ببوابات القطار او مكاتب الاستعلامات، ولذلك اتهمت بانها لا تحقق سوى عدالة شكلية(27)، فالقاضي لا يستطع الوصول الى القانون واجب التطبيق الا بعد الولوج في احدى تلك البوابات،
طبيعة المماية القانونية للحقوق على اختلاف اصنافها، فاذا ما عدنا المى عنصر المماية في كل حق بالمعنى القانوني لوجدنا انه يفتز وجود بجة قضائية همتها حسم منازعات الافراد بشأن حق معين (20)، كما يلزم ان يكون حسم النزاع وفق قواعد قانونية نافذة المفول امام القضاء الناظر في النزاع، وهذا يعني ان المحاية القانونية لاي حق تفترض اولا وجود محكمة وثانيا وجود قانون وبغض النظر عن مصدر ذلك القانون اذ للمحكمة الحكى احيانا حتى باجتهادها في حالة انعدام المصادر الاخرى(21). وفي منازعات القانون الداخلي تكون المحكة وطنية ويكون القانون وطنيا ايضا وبشقيه الموضوعي والاجرائي، اما في منازعات القانون الدولي الخاص فان المحكة تكون وطنية اما القانون فلا يشترط ان يكون وطنيا دائما اذ قد يكون اجنبيا. ان نتي اشتراط وطنية القانون امام المككة بالنسبة لعلاقات القانون الخاص ذات الصفة الدولية عادة ما يتم التعبير عنه بـ"انعدام التلازم" بين الاختصاصين على عكس علاقات القانون العام التي لا زالت القوانين تشترط التلازم بين الاختصاصين القضائي والتشريعي سواء كانت العلاقة وطنية بكامل عناصرها او كانت مشوبة بعنصر اجنبي، فني القانون الجنائي اذا كانت المككة العراقية ختصة وفق احد ضوابط الاختصاص المنصوص عليها في قانون العقوبات فان ذلك يعني اختصاص القانون العراقي بالضرورة ولا يكن تصور تطبيق قانون جنائي اجنبي امام المحاك العراقية، واذا كانت المكمة العراقية غير مختصة بنظر الدعوى الجنائية المرفوعة امامها فانها بكل بساطة تحك بعدم الاختصاص ورد

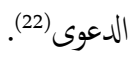

واذا رجعنا الى حالات اختصاص القانون الاجنبي امام المحاك الوطنية بالنسبة لعلاقات القانون الخاص ذات الصفة الدولية، فان لنا ان نتسائل عن نسبة الاختصاص التشريعي الممنوحة للقانون الاجنبي، فهل ان القانون الاجنبي يسري على المنازعة بشكل كمل؟، ان الاجابة على هذا التساؤل تعبر بشكل واضح عن العلاقة بين الاختصاصين القضائي والتشريعي. ولا شك ان الاجابة هي بالنفي، بمعنى اخر ان القانون الاجنبي لا يسري امام المككة الوطنية بشكل كامل وانما على نو جزئي، فن ناحية اولى، الذي يسري من القانون الاجنبي امام المحكة الوطنية هو فقط شقه الموضوعي دون شقه الاجرائي، اذ ان الجانب الاجرائي المتعلق بسير الدعوى امام المحكة يبقى خاضعا دائما للقانون الوطني اي قانون دولة القاضي وبغض النظر عن المبرز (23)، اضافة المى حالات اخرى يتحقق فهيا التلازم بين الاختصاص التشريعي والقضائي كاجراءات التنفيذ الجبري وتدابير الامن المدني ومنها (الاجراءات التحفظية 


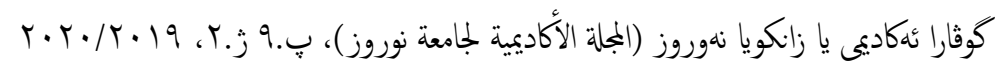

واستنادا على ما سبق، يمكن تعريف التكييف في القانون الدولي الخاص بانه عملية قانونية تستهدف اعطاء الوصف القانوني السليم للعلاقة المشوبة بعنصر اجنبي لغرض تحديد قاعدة الاسناد المختصة بالتطبيق في قانون القاضي ومن ثخ الوصول الى القانون واجب التطبيق على تلك العلاقة(32). وهذه العملية انما هي قانونية لانها تتعلق بانزال وصف قانوني معين على العلاقة كأنزال وصف المسؤولية التعاقدية على المسؤولية الناشئة عن اصابة العمل دون انزال وصف المسؤولية التقصيرية او بالعكس، او انزال وصف الميراث على (نصيب الزوج المحتاج) دون انزال وصف النظام الملالي للزوجين (33)، وهو ما يعني اختلاف قاعدة الاسناد الختصة باختلاف الوصف القانوني المعطى للعلاقة وفي النهاية اختلاف القانون الواجب التطبيق وايضا اختلاف الهحكام القانونية الموضوعية الحاكة لتلك المسؤولية كناصر التعويض عن المسؤولية ونطاقه. ولان التكييف عملية قانونية فانها تخضع لرقابة وتقدير المحكة الهعلى درجة اي ان تكييف محكمة الموضوع يخضع لرقابة محكة الاستئناف بصفتها التميزية وفي كل الاحوال لرقابة محكة التميز(34)، فان اخطأت محكمة الموضوع في تكييف العلاقة القانونية لترتب على ذلك وجود خطأ في تعيين قاعدة الاسناد المختصة ومن ثخ وجود خطأ في تحديد القانون واجب التطبيق وفي النهاية وجود خطأ في الهحكام القانونية الموضوعية، وهنا يلزم من المحكة المعلى درجة نقض ذلك الحكم لتفادي كل تلك الاخطاء الناجة عن الخطأ في تكييف العلاقة. ولاجل تفادي نقض الحكى بسبب الخطأ في التكييف، ينبني على قاضي الموضوع ان يكون حريصا كل الحرص في تكييف العلاقات القانونية في اطار القانون الدولي الخاص، اله ان القاضي كماكان حريصا في تكييفاته القانونية سوف لن يستطع القيام بها في اطار علاقات القانون الدولي الخاص على نو صحيح مالم يكن منفتح الذهن وملما بحد ادنى من المعرفة بالافكار والنظم القانونية في القوانين الاخرى، ولاشك ان ذلك يشكل عبئ ثقيلا على كهل القاضي مقارنة بذات العبء الملقى على عاتقه في اطار علاقات القانون الداخلي، فالاخيرة هي علاقات منتمية بكافة عناصرها للقانون الداخلي ويفترض ان يكون القاضي ملما بها على

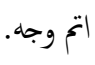
والسؤال الجوهري الذي يطرح بشأن عملية النكييف في القانون الدولي الخاص هو القانون الذي بموجبه يتم تكييف العلاقات القانونية المشوبة بعنصر اجنبي، اذلا يخنى ان نقطة البداية في تحديد الاختصاص التشريعي تبدأ من عملية التكييف(35)، فان كان قانون القاضي هو المعتمد في تكييف هذه العلاقات لتبيّن لنا مدى تاثير الاختصاص
وحتى تفتح احداهن في وجه القاضي ينبني بداية تلوين العلاقة باللون الذي تقبله البوابة فكأن احداها لا تقبل الو اللون الاصفر واخرى لا تقبل اله اللون الازرق وهكذا، فهي لا تفتح الا لما تعارفت عليه، بعبارة اخرى لكي تلج العلاقة في قاعدة الاسناد، واباشراف من القاضي، فاها تتناج الى تذكة دخول، وهذه التذكة لا تمنح الا بعد تكييف العلاقة القانونية وتطابقها مع ما وضعت لها القاعدة من علاقات ابتداء. فعلى سبيل المثل، لا يكن الولوج في قاعدة الاسناد الخاصة بالاهلية الا بعد تكييف المسألة المعروضة امام القاضي بانها من قبيل مسائل الاهلية وبالمثل لا يككن العبور من قاعدة الاسناد الخاصة بالالتزامات غير التعاقدية اله بعد تكييف الالتزام المطروح امام القاضي بانه من طبيعة غير تعقدية، وهكذا بالنسبة لشكل التصرف والزواج والطلاق والوصية والميراث...الخ. 28.). ولعلنا لا نبالغ في القول، ان التكييف عملية قانونية همة ومطلوبة في كل الفروع القانونية، فني القانون الجنائي ينبغي تكييف الفعل الاجراي لاجل تحديد النص الجنائي الواجب التطبيق عليه لاسيم في ظل مبدأ لا جريمة ولا عقوبة الا بنص، وفي القانون المدني ينبني تكييف كل عقد مطروح منازعته امام القضاء لاجل الوصول الى التنظيم القانوني الخاص بذلك العقد لاسيا اذا تم تكييفه بانه من احد العقود المسمة، وبالمثل يلزم تكييف بقية العلاقات القانونية وفي مختلف الفروع القانونية ولذات الهدف اله وهو تحديد النظام القانوني الحلك للعلاقة من الفها المى ياءها. واذا كانت لعملية التكييف اهمية في مختلف الفروع القانونية، فان لها اهمية خاصة وقصوى في القانون الدولي الخاص، لاسيا اذا علمنا ان المشرع عادة ما يقصد في نصوص تنازع القوانين في مقابل اعداد غير محدودة من العلاقات القانونية بين الافراد والتي يشوبها في الوقت ذاته عنصرا اجنبيا(29)، وهو ما يعني انه من المستحيل ان يحكم المحدود او المتناهي (نصوص تنازع القوانين) اللامحدود او غير المتناهي (العلاقات الخاصة الدولية) ما لم توجد عملية يتم فيها اصباغ جميع العلاقات القانونية بتلك الالوان المحدودة التي اودعها المشرع في ذلك الكم القليل من نصوص تنازع القوانين (30. وهذه المسألة يدركها المشرع نفسه عند وضع نصوص تنازع القوانين، اي يدرك انه اتى بنصوص قليلة العدد يعتمد عليها في حسم منازعات هي بالعشرات لا بل مئات العلاقات القانونية ان لم نقل آلاف(31)، ونتيجة لهذا الادراك عادة ما يفرد المشرع نصا خاصا يتناول تكييف العلاقات الخاصة الدولية ويذكر فيه القانون الذي بموجبه يتم تكييف العلاقات

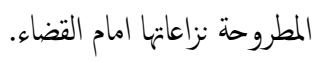




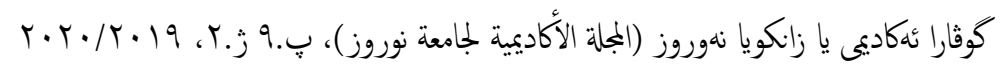

والنظم غير المعروفة في قانونه قيل عليه ان يفعل ذلك بافق واسع وذهن متفتح فنصيب (الزوج المحتاج) ينبني ان يكيف بانه من قبيل الميراث والاقصال الجسماني من قبيل الطلاق وهكذ|(39). وقد انتقلت نظرية قانون القاضي من موقف قضائي مسبق ودع فقهي الى تبني تشريعي من قبل مشرعي معظم دول، فقي القانون العراقي نصت المادة (17) من القانون المدني على ان (1- القانون العراقي هو المرجع في ككيف العلاقات عندما يطلب تحديد نوع هذه العلاقات في قضية تتنازع فيها القوانين لمعرفة القانون الواجب تطبيقه من بينها. 2- ومع ذلك فان القانون الذي يجدد ما اذا كان الشيء عقاراً او منقولاً هو قانون الدولة التي يوجد فهيا هذا الشيء))، وواضح ان القانون العراقي هو المختص بالتطبيق على كل عملية يراد منها تكسيف علاقات القانون الدولي الخاص باستثناء كون المراد هو تحديد طبيعة الشيء كونه عقارا او منقولا حيث يسري قانون الدولة التي يوجد فهها الثيء وهو ذات القانون الذي يهكم الجوانب القانونية الموضوعية المتعقة بالملكية والحقوق العينية الاخرى الواردة على الشيء. واذا رجعنا المى القاعدة في تكييف العلاقات الخاصة الدولية، لجاز لنا القول بثقة ان الاختصاص التشريعي في العلاقات الخاصة الدولية يتأثر أيما تأثير بالاختصاص القضائي الدولي للمحاك الوطنية في مرحلة التكييف، فا ان يعقد الاختصاص للمحاكي العراقية حتى يتولى القانون العراقي تكييف العلاقة المطروحة وتوصيفها التوصيف القانوني المناسب من وبحة نظر المشرع العراقي بغية تحديد قاعدة الاسناد المختصة ومن ثم القانون واجب التطبيق وهكذا بالنسبة للمحاك الاخرى، فالحضانة على سبيل المثال قد تعد من قبيل اثار الزواج في القانون العراقي وبالتالي يسري عليها قانون جنسية الزوج وقت الزواج، وفي محكة اخرى قد تعد من قبيل اثار الطلاق وبالتالي يسري عليها قانون جنسية الزوج وقت الطلاق(40)، فهنا الاختصاص القضائي كان له دور بارز في تحديد الاختصاص التشريعي. واذا اردنا التقليل من اختصاص قانون القاضي في عملية التكييف، فانه يكن اخضاع الوقائع المادية ايضا المى القانون الذي يككم القضية حسب قاعدة الاسناد لاننا امام الوقائع المادية كالعمل غير المشروع يكننا التخلص من تلك الحلقة المفرغة التي تعيق تحديد القانون واجب التطبيق بشأن

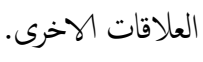

2.3 المطلب الثاني: اثر الاختصاص القضائي الدولي في مرحلة الوخذ بالاحالة بداية ينبني التأيد ان مشكلة الاحلة لا تثور الا اذا اشارت قاعدة الاسناد الوطنية الى تطبيق قانون اجنبي، بمعنى لا نكون امام مشكلة الاحالة اذا كان قانون القاضي
القضائي في تحديد الاختصاص التشريعي، فتى ما عقد الاختصاص القضائي لمحاكي دولة معينة فان قانون هذه الدولة ذاتها سيحدد لنا طبيعة العلاقات واوصافها القانونية وهو ما يعني اختلاف تكييف ذات العلاقة باختلاف المككة المرفوع اماما النزاع، بعبارة اخرى الذي يصبن العلاقات بصبغة معينة في سبيل تحديد قاعدة الاسناد الختصة والاختصاص التشريعي هو قانون المحكة والذي يعبر عن رؤية مشرعه الوطني لما ينبني ان تكون عليه طبيعة العلاقة القانونية، وقد يتزتب على ذلك ان ذات المسألة (كضر اجراء الوصية بالشكل العرفي) تعد من قبيل الاهلية في قانون الدولة (س) بينا تعد من قبيل المسائل المتعلقة بشكل التصرف في قانون الدولة (ص) ومن ثخ اختلاف قاعدة الاسناد المختصة والاختصاص التشريعي لنات المسألة باختلاف الاختصاص القضائي الدولي. ولاجل تلافي هكذا نتيجة، يدعوا جانب من الفقه الى الزام القاضي بتكييف علاقات القانون الدولي الخاص وفق (القانون المقارن) والذي يعني تلك الافكار والنظم القانونية المشتركة على مستوى العالم، فا يعد من قبيل الاهلية يجب ان يكون كذلك في القانون المقارن وليس وفق ما يتصوره قانون القاضي وحده، وهكذا بالنسبة لبقية العلاقات. الح ان ما يؤخذ على هذه الدعوة هو مبالغتها في المثالية ومجافها للواقع حيث من الصعب ايجاد نظم وافكار قانونية مشتركة لاسيا في مجال الاحوال الشخصية اضافة الى تحميلها للقاضي عبئًا ثقيلا تيتثل في معرفته بالنظم

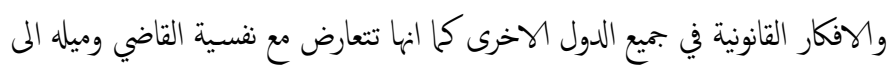
تطبيق قانونه الوطني (36). وفي المقابل، يدعوا جانب اخر من الفقه الى اجراء عملية التكييف وفق القانون الذي يحكم المسألة اصلا والذي بدوره قد يكون قانون القاضي او قانونا اجنبيا حسب ما تقضي به قاعدة الاسناد الوطنية، ويستند هذا الراي على عدة جج اهها ان الاختصاص للقانون واجب التطبيق ينبني ان يكون اجاليا ولا يتحقق ذلك ال اذا شُمل النكييف ايضا باحكامه، الوان علة هذا الرأي ان فيه مصادرة على المطلوب حيث اننا نقوم بالتكيف اصلا لاجل تحديد قاعدة الاسناد المختصة والقانون واجب التطبيق فكيف لنا ان نكييف حسب القانون واجب التطبيق وهو غير معلوم بعد (37). ونتيجة لعدم صمود النظريتين السابتتين امام الانتقادات الموبجة لما، تربعت نظرية قانون القاضي على عرش القانون الحاكم لعملية النكييف مستندة على الكثير من الحجج لعل اهها هو ان التكيف يعد تفسيرا لقاعدة الاسناد الوطنية ولا يككن تفسير القاعدة الوطنية الا وفق مبادئ التفسير في قانون القاضي (38. ولاجل احاطة القاضي بالافكار 


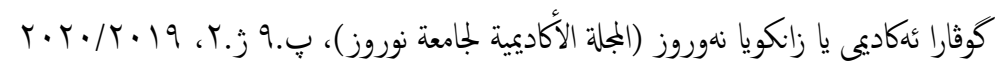

الناحية ايضا عادة ما بيمل الى تطبيق قانونه، فاكانت الوحالة اله ذريعة لترك الامر التشريعي الموجود في قاعدة الاسناد الوطنية والذي امر بتطبيق قانون اجنبي والعودة مرة اخرى وبطريقة قانونية الى قانونه الوطني، والطريقة القانونية المشار الهيا تم تبريرها في ان القاضي الوطني يجب ان لا يكون اكثر حرصا من المشرع الاجنبي نقسه، فالمشرع الاجنبي (البافاري) رفض الاختصاص التشريعي على اساس الموطن، اذن لما سيبقى القاضي الفرني حريصا ومصرا على اعطاء الاختصاص التشريعي لذلك

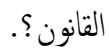
لاشك ان الاخذ بالاحالة سيكون على حساب نسبة اختصاص القانون الاجنبي واجب التطبيق وفق قاعدة الاسناد الوطنية، فعلى سبيل المثال اذا قلنا ان نسبة اختصاص القانون الاجنبي امام المحاك الوطنية هي 50\% والنسبة الباقية هي لقانون القاضي حسب قاعدة الاسناد ننسها، فان نسبة اختصاص قانون القاضي ستزيد (لتكون مثلا 75\%) بعد الاخذ بالاحالة لاسيا ان القاضي عادة ما ياخذ بالاحالة للقانون الوطني دون ان يكون حريصا عليها في حالة الاحالة لدولة ثالثة. ويبدو واضحا ان النسبة الاضافية من الاختصاص التشريعي العائد الى القانون الوطني بطريق الاحالة انماكان بتأثير الاختصاص القضائي الدولي للمحاكم، فلان اختصاص النظر في قضية التزكة المذكورة انفا عقدت للمحكاك الفرنسية فان الاحالة ادت الى اختصاص القانون الفرنسي (قانون القاضي) بعد ان اسندت قاعدة التنازع الفرنسية الاختصاص لقانون اجنبي بداية، ولو عكسنا المسألة لرأينا ارتباط الاختصاص التشريعي بالاختصاص القضائي على نحو كلما عقد الاختصاص القضائي لمكمة دولة ما عاد الاختصاص التشريعي لقانون ذات المحكة بطريق الاحالة، فاذا افترضنا ان قضية التركة المذكورة لم تعرض على المحاك الفرنسية بداية انما بالعكس عرضت على المحاك البافارية وهي محاكم موطن الشخص المتوفى، فان الاختصاص التشريعي حسب قاعدة الاسناد البافارية سيكون لقانون محل اقامة المتوفى وهو القانون الفرني، وعلى فرض ان المحكة البافارية على غرار المكمة الفرنسية ايضا استشارت قاعدة الاسناد الفرنسية لوجدت ان القانون الفرني يرفض الاختصاص في النظر في دعوى تركة الشخص على اساس الاقامة المعتادة بل تحيل الاختصاص الى قانون موطن المتوفى وهو القانون البافاري، وهذا دليل قاطع على قولنا ان الاختصاص التشريعي المتأتي من الاحالة انما يعتمد الاختصاص القضائي في الدرجة الاولى.
هو القانون واجب التطبيق، فان حدث ان اختص القانون الاجنبي فان السؤال المثار يتعلق بوجوب استشارة قواعد الاسناد في ذلك القانون من عدمه(41)، فاذا قلنا بوجوب استشارة قواعد الاسناد في القانون الاجنبي انما يكون ذلك بهدف التأكد من قبول القانون الاجنبي للاختصاص المحال له حسب قواعد الاسناد في قانون القاضي او رفضه للاختصاص ومن ثم احالته المى قانون اخر والاخير قد يكون قانون القاضي ذاته او قانون دولة ثالثة، وفي حالة رضض القانون الاجنبي للاختصاص يعمل القاضي بذلك الرفض ويأخذ بتلك الحالة الى قانون اخر سواءكان قانون القاضي او قانون دولة ثالثة. فعلى سبيل المثال، اذا اثير بشأن اهلية شخص يحمل الجنسية البريطانية ومتوطن في العراق دعوى امام المحاك العراقية فان القانون واجب التطبيق حسب قاعدة الاسناد في القانون العراقي سيكون قانون جنسية الشخص وهو في المثال القانون البريطاني، ولكن اذا استشار القاضي العراقي قواعد الاسناد في القانون البريطاني فانه سيجد ان القانون الاخير يرفض الاختصاص المحال له حسب القانون العراقي ويحيله الى القانون العراقي ذاته باعتبار ان القانون واجب التطبيق على الاهلية في القانون البريطاني هو قانون موطن الشخص، والاخير موطنه في المثال هو العراق. واذا عدلنا في المثال المذكور انفا وقلنا ان الشخص يحمل الجنسية البريطانية ولكنه متوطن في الهند، فان القانون البريطاني سيرفض الاختصاص مرة اخرى ولكن سيحيله الى قانون دولة ثالثة ال وهو القانون الهندي باعتبار توطن الشخص هناكـ(42). وتاريخيا، ظهرت مشكلة الاحالة بمناسبة قضية عرضت على القضاء الفرني متعقلة بتركة شخص اجنبي متوفى في فرنسا، في تلك القضية كان القانون واجب التطبيق هو قانون اجنبي (القانون البافاري) وفق ظابط موطن الشخص الوارد في قاعدة الاسناد الفرنية(43)، وبعد امعان النظر في القانون الاجنبي وجد المدعي العام الفرني ان قواعد الاسناد فيه ترفض الاختصاص على اساس الموطن وتحيله الى قانون الدولة التي يقيم فيها الشخص وكان المتوفى مقيا في فرنسا، حينها لم تتردد المككة الفرنسية في الاخذ باحالة القانون الاجنبي واجب التطبيق، لان في ذلك توسيعا لنطاق تطبيق القانون الوطني والذي قضى في النهاية بايلولة تركة الاجنبي الذي لا وارث له الى الحكومة الفرنسية، وفي ذلك ما فيه من استجابة للميل النفسي للقاضي حيث عادة ما يميل الى تطبيق قانونه الوطني، فكأن الاخذ بالاحالة حققت هدفين مرغوبين لدى القاضي اولما توسيع نطاق تطبيق قانون القاضي، وثانيا القاضي يعلم قانونه الوطني وقد لا يعلم او يجد صعوبة في معرفة القانون الاجنبي فن هذه 


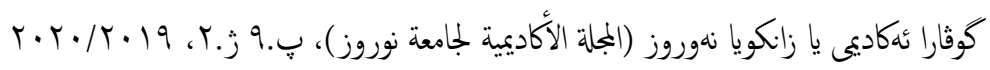

التي ينتي اليها بجنسيته، فان كان الملتزم انكليزيا كان القانون البريطاني هو الواجب التطبيق مع السحاح للقاضي العراقي باستشارة قواعد تنازع القوانين في القانون البريطاني فان احال هذا القانون الاختصاص الى قانون موطن الملتزم بالحوالة ولنفترض انه متوطن في دولة الامارات العربية المتحدة فان القاضي العراقي عليه تطبيق القواعد الموضوعية في القانون الاماراتي دون القواعد المتعلقة بتنازع القوانين في القنانون الاخير ، ونتثقد ان النص على الاخذ بالاحالة بدرجة واحدة هو للتحرز من الوقوع في حلقة مفرغة (46).

ومن وبجة نظر موضوعية منطلقة من زاوية استقلال الاختصاص القضائي عن الاختصاص التشريعي، فاننا نويد الموقف التشريعي الرافض لفكرة الاحالة لانها بالفعل تؤدي الى توسيع نطاق تطبيق قانون القاضي على حساب نطاق القانون الاجنبي لاسيا ان المبدأ في تنازع القوانين هو اسناد العلاقة المى اكثر القوانين صلة بالعلاقة والذي يتحقق فيه العدالة والملائمية اكثر سواءكان قانون القاضي او قانون اجنبي. 4. المبحث الثالث: اثر الاختصاص القضائي الدولي في تحديد القانون واجب التطبيق في حالتي استبعاد القانون الاجنبي وتعذر الوصول اليه

لطالما انتقد منهج قاعدة الاسناد بانه يتسم بالتعقيد وتعدد العمليات الفنية التي ينبغي تجاوزها بهدف الوصول المى النصوص القانونية الموضوعية واجبة التطبيق على العلاقة، وما يشهد على ذلك ان القاضي بعد اجتيازه مرحلتي التكييف والاحالة فانه يكون امام احتالين اولما وجود مانع من موانع تطبيق القانون الاجنبي كخالفنه للنظام العام في دولة القاضي، وثانيها هو تعذر اثبات القانون الاجنبي واجب التطبيق اصلا لوجود علة في قاعدة الاسناد الوطنية، وفي الاحتالين المشار اليها يؤثر مرة اخرى الاختصاص القضائي الدولي للمحاكم في الاختصاص التشريعي. ولاجل الاحاطة بما ذكر، سنقسم هذا المبحث المى مطلبين نخصص الوول منها لاثر الاختصاص القضائي في تحديد القانون واجب التطبيق في حالة استبعاد القانون الاجنبي، اما المطلب الثاني فسنتناول فيه اثر الاختصاص القضائي في تحديد القانون واجب التطبيق في حالة

$$
\text { تعذر الوصول للقانون الاجنبي. }
$$

1.4 المطلب الاول: اثر الاختصاص القضائي في تحديد القانون واجب التطبيق في حالة استبعاد القانون الاجنبي

لقد تنهت نظريات تنازع القوانين منذ بدايات نشأتها المى امر هم الا وهو ان سماح المشرع الوطني بتطبيق قانون اجنبي، باعتبار انه القانون الاكثر صلة بالعلاقة وانه
بعد موقف القضاء الفرني من الاحالة، اعتبر الفقه الاحالة كنظرية وراح يبحث فيها الح انه انتسم على نسه بين مؤيد ومعارض لها، اما من ايد فكرة الاحالة فقد استند على عدة ججج لعل اهما ان الاختصاص التشريعي للقانون الاجنبي ينبني ان يكون اختصاصا اجاليا بمعنى ينبغي تطبيق كل قواعد القانون الاجنبي بما في ذلك قواعده المتعلقة بتنازع القوانين لانها ان قبلت الاختصاص فان في ذلك توحيدا للحلول وسهولة في تنفيذ الاحكام القضائية الاجنبية وان رفضت واحالة الاختصاص الى قانون اخر فان العمل بالاحالة فيه احترام لارادة تلك القاعدة ومرة اخرى توحيدا للحلول القانونية بين الدول والذي يعد من اهداف القانون الدولي الخاص(44). اما من عارض فكرة الاحالة فقد رد على معظم ججج مناصمها، فقول الانصار ان القانون الاجنبي كل لا يتجزأ بمعى ضرورة تطبيق قواعده المتعلقة بتنازع القوانين قول مردود عليه بان قانون القاضي ايضاكل لا يتجزأ فالذي يحصل نتيجة العمل بالاحالة هو اهمال الحكم الوارد في قاعدة تنازع القوانين في قانون القاضي، لا بل ان العمل بالاحالة يؤدي الى ان يأتمر القاضي الوطني بأوامر المثرع الاجنبي وهذا قول لم يجوزه احد لحد الان ، ففي القضية التي ذكرناها انفا عمل القاضي الفرني بأمر المشرع البافاري عندما اخذ بالاحالة الواردة اليه من قاعدة التنازع البافارية(45). وبالنظر الى قوة ججج معارضي الحالة، رفضت اغلب القوانين الاخذ بالاحالة ومنها القانون العراقي، فالفقرة الاولى من المادة (31) من القانون المدني العراقي نصت على انه ((اذا تقرر ان قانوناً اجنبياً هو واجب التطبيق فإنما يطبق منه احكامه الموضوعية دون التي تتعلق بالقانون الدولي الخاص))، فسب هذا النص اذ اختص قانون اجنبي في حكم علاقة خاصة دولية وفقا لقاعدة الاسناد العراقية فان القاضي العراقي يذهب مباشرة الى الاحكام الموضوعية في ذلك القانون دون ان يستشير قاعدة الاسناد في ذلك القانون الاجنبي. ومع ذلك، فقد اخذ المشرع العراقي بالاحالة على سبيل الاستثناء في قانون التجارة العراقي رق (30) لعام 1984 بشأن اهلية الملتزم بمقتى حوالة تجارية، فالفقرة ثانيا من المادة (48) نصت على انه ((يرجع في تحديد الالتزام بمتضى الحوالة الى قانون الدولة التي ينتي الهيا الملتزم بجنسيته. فاذا احال هذا القانون الى قانون دولة اخرى كانت القواعد الموضوعية في قانون تلك الدولة الواجبة التطبيق)). ان الاخذ بالاحالة في النص المذكور واضح وجلي، الا ان ما ينبني تسجيله في هذا المقام هو ان الحالة يعمل بها بدرجة واحدة وليس بدرجتين او اكثر، فالاحالة بدرجة واحدة تعني ان القاضي العراقي يطبق على اهلية الملتزم بالحوالة قانون الدولة 


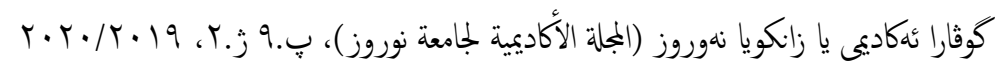

فان ذلك القانون الاجنبي يستبعد من دائرة حكم العلاقة ويحل محله القانون العراقي(50)، ولو ان ذات العلاقة رفعت امام المحاكم المصرية مثلا واشارت قاعدة الاسناد المصرية المى ذات القانون الاجنبي ثم تبيّن انه خخالف للنظام العام المصري فان القانون الاجنبي يستبعد مرة اخرى ولكن يجل محله هذه المرة القانون المصري وليس القانون العراقي، فكأن اختصاص القانون العراقي والمصري في الحالينن جاء نتيجة عقد الاختصاص القضائي الدولي لمحاكها بداية. واذا تفحصنا بقية موانع تطبيق القنون الاجنبي لوجدنا ان ما قيل بشأن النظام العام ينطبق عليها غالبا، فاستبعاد القانون الاجنبي باسم المصلحة الوطنية يترتب عليه تطبيق الحكى الموجود في قانون القاضي (51)، وهذا ما اشارت اليه صراحة الفقرة الثانية من المادة (18) من القانون المدني العراقي اذ جاء فيها انه ((...في التصرفات المالية التي تعقد في العراق وتترتب اثارها فيه، اذا كان احد الطرفين اجنبياً ناقص الاهلية وكان سبب نقص اهليته يرجع الى سبب فيه خفاء لا يسهل على الطرف الآخر تبينه، فان الاجنبي يعتبر في هذا التصرف كمل الاهلية)). كما ان استبعاد القانون واجب التطبيق بحجة الغش نخو القانون قد يؤدي الى جلب الاختصاص التشريعي لقانون القاضي في حالة ما اذا كان هو القانون واجب التطبيق اصلا قبل حصول عملية الغش(52)، الا انه ليس بالضرورة جلب الاختصاص لقانون القاضي في هذه الحالة لانه يعطى الاختصاص للقانون واجب التطبيق قبل حصول الغش والذي قد يكون قانون القاضي او قانون اخر (53.) واخيرا يككن اعتبار تطبيق القواعد ذات التطبيق الضروري (قواعد البوليس) في قانون القاضي من قبيل موانع تطبيق القانون الاجنبي، فتطبيق هذه القواعد يكون بالاولوية على تطبيق القانون الاجنبي وعلى حسابها، فني كل علاقة قانونية محكومة بقانون اجنبي امام القاضي العراقي على الاخير قبل تطبيق القانون الاجنبي ان ينظر في القانون العراقي ان كانت فيه قواعد متعلقة بالامن المدني تدخل العلاقة المنظورة امامه في نطاق سريانها فان وجد قاعدة من تلك القواعد ذات التطبيق الضروري طبقها اولا وهو ما يعني استبعاد جزء من القانون الاجنبي واجب التطبيق. نستنج مما سبق ان الاختصاص التنريعي يتأثر بالاختصاص القضائي الدولي في معظم حالات استبعاد القانون الاجنبي على نحو يحل قانون القاضي محله، بعبارة اخرى تزداد نسبة اختصاص قانون القاضي على حساب نسبة اختصاص القانون الاجنبي كلما عقد الاختصاص القضائي الدولي لمحاك دولة القاضي.
الاكثر عدالة وملائمة، ليس سلحا مفتوها دون قيد او شرط ولا هو توقيع على بياض يجيز تطيق القانون الاجنبي في كل الاحوال، انما الصحيح هو سلح مقيد بعدم الاضرار بالمصلحة الوطنية لدولة القاضي وكذلك عدم النعارض مع نظامه العام الوطني او عدم وجود عملية تحايل على القانون من قبل الافراد او عدم وجود قواعد متعلقة بالامن المدني في دولة القاضي. فاذا رجعنا الى القرن الرابع عشر من الميلاد وقت بروز نظرية الاحوال الايطالية القديمة لوجدنا ان الفقه الايطالي في ذلك الوقت ميّز بين نوعين من الاحوال (اي القوانين)، فهناك احوال مستحسنة لا مانع من تطبيقها شخصيا اي تتبع الشخص اينا حل، وهناك احوال مستهنة ينبني ان تبقى اقليمة ولا يمند نطاق تطبيقها خارج حدود السلطة التي اصدرتها(47)، بعبارة اخرى ان الاحوال المستهجنة التي قال باقلميتها الفقه الايطالي القديم انماكان الاساس الولي لفكرة النظام العام في القانون الدولي الخاص، وبالفعل عندما تمت صياغة قواعد تشريعية في حل مشكلة تنازع القوانين والتي تجيز تطبيق قانون اجنبي، احتاط المشرعون لانهم تصوروا اشارة قاعدة الاسناد الى قوانين اجنبية ظالمة او وحشية او غير منطقية او مخالفة للنظام العام في دولنه، لذلك نجده قد قيدوا تطبيق ذلك القانون بشرط عدم مخالفته للنظام العام في دولة القاضي (48.) وكمطم المشرعين ، احتاط المشرع العراقي ايضا في قواعد المتعلقة بتنازع القوانين وقيد سهاحه بتطبيق القانون الاجنبي بعدم خخالفته للنظام العام في العراق، فجاء في نص المادة (32) من القانون المدني العراقي انه (لالا يجوز تطبيق احكام قانون اجنبي قررته النصوص السابقة اذا كانت هذه الهحكم مخالفة للنظام العام او للآداب في العراق)). فعلى سبيل المثال، لا يككن تطبيق قانون اجنبي في العراق يعزف بنظام التبني وينظمه او قانون اجنبي يجيز سعر فاحش للفائدة في التعاملات المالية. لذلك، عليه فان كل حكم قانوني اجنبي مخالف للنظام العام في العراق يتم استبعاده من قبل القاضي، ولكن السؤال الجوهري في هذا المقام متعلق بالقانون الذي يحل محل القانون الاجنبي المستبعد كليا او جزئيا(49). وفي الاجابة، يذهب الفقه الى طرح اكثر من بديل عن القانون الاجنبي المستبعد الا ان الرابح هو تطبيق قانون القاضي اي قانون دولة المحكة المرفوع اماها النزاع بشأن علاقة خاصة دولية، وهكذا بدا جليا مدى تاثير الاختصاص القضائي الدولي للمحاك في تحديد الاختصاص التشريعي في حالة استبعاد القانون الاجنبي، فلان الاختصاص القضائي الدولي عقد للمحاك؟ العراقية مثلا ولان القانون الاجنبي واجب التطبيق قاعدة الاسناد العراقية هو خخالف للنظام العام او الاداب العامة في العراق 


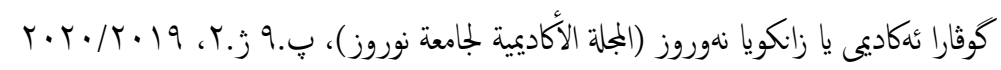

في القاعدة بمعنى اذا لم نستطع الوصول المى القانون واجب التطبيق وفق هذا الضابط لكنا امام تعذر الوصول المى القانون الاجنبي واجب التطبيق مرة اخرى(56)، فلنتصور الان ان عقدا لبيع بضاعة تم عبر وسائل الاتصال الالكترونية كالفاكس والاميل وغيرها بين مشتري عراقي متوطن في الاردن وبائع صيني متوطن في الولايات المتحدة الامريكة، فكلان ابرام العقد افتراضي لعدم اتحاد مجلس العقد في مكان واحد وقت الابرام، علما ان هذا المكان في غاية الاهمية لانه يحدد لنا القانون واجب التطبيق على منازعات هكذا عقد، وقد يقول قائل ان القانون الاجنبي في هذه الحالة يككن الوصول اليه عبر تطبيق نظريات تحديد مكان العقد في حالة التعاقد بين غائبين، وهذا صحيح مبدئيا حيث ان الرابح منها تشير ان مكان ابرام العقد هو مكان علم الموجب بالقبول (57)، ومع ذلك فان فرضية عدم الوصول الى القانون الاجنبي تبقى قائمة في حالة علم الموجب بالقبول على متن باخرة في عرض البحر او على متن طائزة محلقة في الاجواء الدولية، وهذا يعني اللجوء مرة اخرى الى الاحتياط المتثل بقانون القاضي. ولنأخذ مثالا ثانيا، متعلقا بالمسؤولية المدنية الناشئة عن انتهاك الحق في السمعة عبر مواقع التواصل الاجتاعي، ان قاعدة الاسناد المنطبقة في هذه الحالة هي القاعدة المتعلقة بالالتزامات غير التعاقدية والتي تشير، كما ذكرنا انفا، المى تطبيق قانون الدولة التي حدثت فهيا الواقعة المنشئة للالتزام، فالبنسبة للمثال المذكور يثور التساءل عن المقصود بالواقعة هل هو الفعل ام الضر؟، لان الغالب في هكذا انتهاك ان يكون الفعل في دولة والضرر في دولة اخرى(58)، لا بل ان الفعل قد يكون افعالا متعددة ومرتكبة في دول متعدد كما لو تم التشهير بسمعة شخص نتيجة عبارة او مقالة كنبت في العراق وطبعت في الاردن ووضعت على مواقع التواصل الاجتماعي في فرنسا، فاي دولة من الدولة المذكورة وقع فها الفعل المنشئ للالتزام؟، وحتى اذا افترضنا ان المقصود بالواقعة هو الضرر فانه يحتمل ان يحدث في عشرات الدول لا بل في معظم دول العالم لاسيا اذا كنا امام تشهير بسمعة شخصية سياسية او فنية او رياضية مشهورة عالميا(59)، فكل دولة يكون فيها الشخص المنتهك سمعته معروفا لدى افراد لايهم اتصال بشبكة الانتزنت تكون دولة واقعة فهيا الضرر المنشئ للمسؤولية المدنية عن انتهاك الحق في السمعة. وفي هذه الحالة، ستكون دولة القاضي من بين تلك رن الدول التي حدثت فيها الضرر ومن ثخ يعطى الاختصاص لقانون القاضي ليس لانه افضل القوانين واكثرها ملائمة لحكى العلاقة وانما اختص بمناسبة الاختصاص القضائي، ولهذا نرى في مثل هذا النوع من الاتهاكات الحاصلة عبر وسائل الهعلام نوعا من

\section{4 المطلب الثاني: اثر الاختصاص القضائي في تحديد القانون واجب الثطبيق في حالة تعذر الوصول للقانون الاجنبي}

ان احدى المسائل التي يعاب فيه منهج قاعدة الاسناد هو احتالية تعذر الوصول للقانون الاجنبي واجب التطبيق في نهاية كل الاشواط التي قطعها القاضي ضمن آليات المنهج المذكور من تكييف وتطبيق لقاعدة الاسناد الوطنية واخذ بالاحالة او رفضها وغير ذلك، وهو ما يعني ان نتيجة تطبيق المنهج هو لا شيء وان العلاقة القانونية لا زالت في حاجة المى قانون ينظمها ويحسم منازعاتها. ان هكذا نتيجة تشكل في الوقت ذاته خيبة للقاضي تدعوه الى عدم تحبيذ هكذا منهج، والميل الى توسيع نطاق تطبيق تشريعه الوطني المتَّتي من الاختصاص القضائي (54). وقد يتعذر الوصول الى القانون واجب التطبيق نتيجة وجود عوق ذاتي في قاعدة الاسناد ذاتها، وعادة ما يبرز عوق قاعدة الاسناد امام العلاقات القانونية التي لم يأخذ المشرع ظروفها في الحسبان عند وضع القاعدة او تلك العلاقات التي يدخل في بناءها عناصر النكنولوجيا الحديثة. فعلى سبيل المثال، تشير قاعدة الاسناد التقليدية بشأن الالتزامات غير التعاقدية الى تطبيق قانون الدولة التي حدثت فيها الواقعة المنشئة للالتزام(55)، وواضح ان القاعدة تفنزض دائما وجود دولة وقانون في مكان حدوث الواقعة المنشئة للالتزام، ولكن اطلاق هذا الافتراض ليس في محله فقد يحصل ان تحدث الوقعة المنشئة للالتزام غير التعاقدي في مكان ينعدم فيه سلطة دولة بعينها كما لو حدثت الواقعة على متن باخرة في عرض البحر ، وبعد ذلك طرح المدعي بالحق في التعويض دعواه امام محاك الدولة (س)، فلاشك ان قاعدة الاسناد المذكورة ستكون عاجزة عن الوصول للقانون واجب التطبيق وفق ما تقضي به القاعدة، ولا يسمح للقاضي رد الدعوى بحجة عدم الوصول للقانون واجب التطبيق بل لابد من تحديد قانون اخر يكون بديلا عن القانون واجب التطبيق في الاصل، ولا غرابة اذا قلنا ان البديل في الكثير من الاحيان يكون قانون القاضي نفسه باعتبار ان لهذا القانون دورا احتياطيا يمارسه كلما جز القاضي عن الوصول للقانون الاجنبي واجب النطبيق. ويبدو جليا مرة اخرى، ان الذي جلب الاختصاص التشريعي لقانون القاضي هو الاختصاص القضائي. كما يككن ان يبرز العوق الذاتي في قواعد الاسناد التقليدية نتيجة التطور التكنولوجي الهائل في ميدان الاتصال والمواصلات، فالقاعدة التقليدية بشأن الانزامات التعاقدية تشير الى تطبيق قانون محل ابرام العقد، وهو الضابط الهسنادي الاحتياطي الاخير 


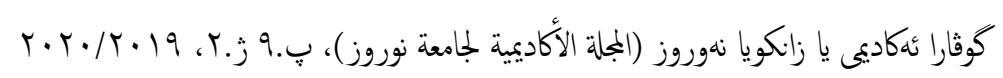

التسوق القانوني، فها على المدعي سوى اختيار المحكة حتى يكون قانونا ختصا 1.5 الاستنتاجات

من حيث المبدأ يستقل كل من الاختصاص القضائي الدولي للمحاك الوطنية والاختصاص التشريعي عن بعضها البعض، فلكل اختصاص قواعده الخاصة والتي تختلف بالضرورة عن بعضها، اذ على الاقل تكون قواعد الاختصاص التشريعي ذات طبيعة مزدوجة بينما يجب ان تكون قواعد الاختصاص القضائي الدولي مفردة الجانب لا تحدد الا اختصاص المحاك الوطنية. ومع ذلك، فان مجرد عقد الاختصاص للمحاكم الوطنية لدولة معينة حتى يؤثر ذلك وبشكل كير في تحديد الاختصاص التشريعي وعادة ما يكون لصالح قانون المحكة على حساب القوانين الاجنبية. ان الكثير من جوانب الاختصاص التشريعي في العلاقات الخاصة الدولية تحسم لصالح قانون المككة باعتبارها جوانب لا تنازعية او لا تقبل التنازع لحد الان، كاجراءات الدعوى والمرافعة والتنفيذ العيني الجبري وتدابير الامن المدني وهو اختصاص يبره العديد من الاعتبارات، وبمناسبة عقد الاختصاص القضائي لمحاكم دولة معينة تحسم جوانب اخرى من الاختصاص التشريعي لصالح قانون المحكة اما اصالة وفق قاعدة الاسناد ذاتها او على وجه الاحتياط. يتأثر الاختصاص التشريعي في مرحلة النكييف بالاختصاص القضائي الدولي، فا ان ينعقد الاختصاص القضائي لمحاكم دولة معينة حتى يتولى قانون المككة ذاتها توصيف العلاقات المطروحة نزاعتها اماها بالاوصاف القانونية المناسبة من وبهة نظر المثرع الوطني في دولة المحكمة بغية تحديد قاعدة الاسناد المختصة ومن ثم

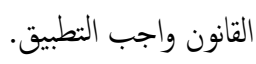

ان الاخذ بالاحالة الى قانون المحكمة يؤدي الى توسيع نطاق تطبيق قانونه على حساب القوانين الاجنبية، ومرة اخرى الذي جلب الاختصاص التشريعي لقانون المككة هو الاختصاص القضائي الدولي للمحاك الوطنية.

في معظم حالات استبعاد القانون الاجنبي لوجود مانغ من موانع تطبيقه عادة ما يكون البديل عن النص او القانون الاجنبي المستبعد نص او قانون المحكة ذاتها، فالذي يجلب الاختصاص التشريعي لقانون المحكة في حالات استبعاد القانون الاجنبي واجب التطبيق وفق قاعدة الاسناد الوطنية هو الاختصاص القضائي للمحاكم الوطنية.
بالتطبيق نظرا لحدوث الضرر او نسبة من الضرر في دولة القاضي، فكأن المدعي يتفحص القوانين المتصلة بالعلاقة اولا ويختار منها ما يلبي ادعاءاته وهو اختيار مضمون الم درجة كيرة من خلال اختيار المحكمة (60). اما بشأن تعذر اثبات القانون الاجنبي، فعروف ان الاثبات بحد ذاته اثار جدلا كيرا في الفقه، فهل ان اثبات القانون الاجنبي مطلوب من الاطراف في الدعوى باعتبار ان القانون الاجنبي من عناصر الواقع في الدعوى وليس القانون وهو ما يؤدي الى نتيجة بسيطة تتمثل في عدم تطلب علم القاضي بالقانون الاجنبي؟، ام ان القانون الاجنبي لا يفقد صفته الرسمية بمجرد عبوره حدود السلطة التي اصدرته اي يبقى من عناصر القانون وهو ما يؤدي الى القول بافتراض علم القاضي بالقانون الاجنبي(61). على اية حال، واياكانت طبيعة القانون الاجنبي امام المحكة الوطنية، فان الرابح هو تعاون اطراف الدعوى مع القاضي في اثبات القانون الاجنبي من خلال نصوص قانونية رسمية معترف بها في دولة القاضي ومترجمة بلغة القاضي، او حتى عبر مصنفات اكلديمية وفقهية كتبت في القانون الاجنبي (62). ولكن احتالية تعذر اثبات القانون الاجبي تبقى قائمة رغز التوصية بتعاون اطراف الدعوى مع القاضي في اثبات القانون الاجنبي، ولو ان هذه الاحتالية تضاءلت في الوقت الحاضر بحكم العولمة وسهولة التواصل بين الدولة اضافة الى قيام معظم الدول بابرام اتفاقيات تعاون قضائية وقانونية على الاقل على المستوى الوقليم، كما تنحوا معظم الدول حاليا الى اتاحة تشريعاتها المهمة بلغة دولية كالانكليزية على شبكة الاتتزيت، رغز ذلك لا نستطيع القول بمضمونية اثبات القانون الاجنبي في كل الاحوال، فاحتال تعذر الاثبات تبقى قائمة كأن يكون القانون واجب التطبيق قانون دولة لا زالت نامية جدا بعيدة عن ركب العولمة، واذا طرحنا البديل في هكذا حالة فلاشك ان البديل هو العودة للاصل المتثل بتطبيق قانون القاضي، مرة اخرى الذي جلب الاختصاص التشريعي لقانون القاضي في حال تعذر اثبات القانون الاجنبي هو انعقاد الاختصاص القضائي للمحاكي الوطنية.

\section{5. الخائمة}

بعد الانتهاء من كتابة هذا البحث، فاننا نزع التوصل الى جملة من الاستناجات والتوصيات والتي نجملها على النحو الاتي: 


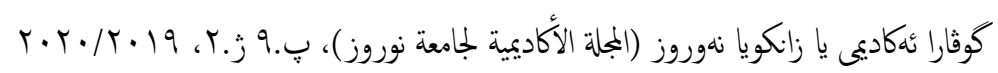

ندعو وزارة العدل العراقية ووزارة العدل في اقليم كوردستان-العراق الى الاهتمام باتاحة التشريعات الوطنية بلغة دولية (كترجتها للغة الانكليزية) وان تكون متوفرة على شبكة الاتتريت، فقد تكون تشريعاتنا الوطنية واجبة التطبيق امام محكة اجنبية وفقا لقواعد الاسناد في تلك الدولة، وما ان يتعذر على تلك تك المحكة اثبات القانون العراقي حتى يتم حسم الدعوى في الغالب وفقا لقانون تلك المحكة، والحال ان دعاوى العراقيين امام المحاك الاجنبية ليست بالعدد القليل

$$
\text { بحكم تواجد الملايين من العراقيين في الخارج. }
$$

6. - المراجع

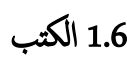

1. د. احمد عبدالكريم سلامة، فقه المرافعات المدنية الدولية، ج1، ط1، دار النضة العربية،

القاهرة، 2000.

2. د. امد عبدالكريم سلامة، القانون الدولي الخاص الهماراتي، مطبوعات جامعة الحمارات

العربية المتحدة، العين، 2002.

بيار ماير وفانسان هوزيه، القانون الدولي الحاص، ترجمة د. علي محمود مقلد، مجد المؤسسة

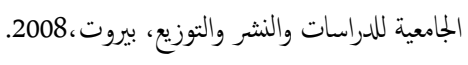

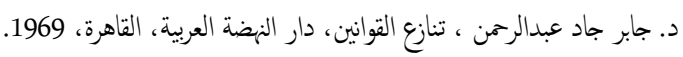

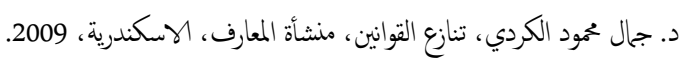

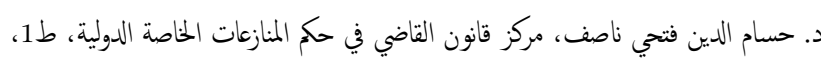

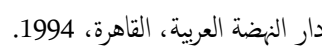

د. حسن الهداوي، تنازع القوانين واحكامه في القانون الدولي الخاص الكويتي، مطبوعات

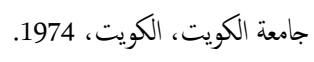

د. حسن محمد الهداوي ود. غالب على الداودي، القانون الدولي الخاص، ج2، وزارة التعليم

$$
\text { العالي والبحث العلمي، بغداد، } 1988 .
$$

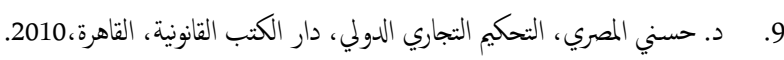

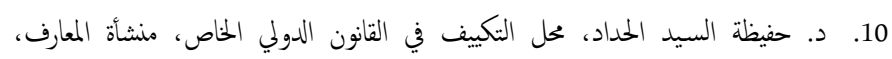

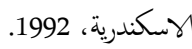

11. د. حفيظة السيد حداد، القانون الدولي الخاص، الكتاب الاول، تنازع القوانين، منشورات

$$
\text { الحلبي الحقوقية، بيروت، } 2002 .
$$

12. د. ساي بديع منصور و د. اسامة العجوز، القانون الدولي الحاص، ط3، منشورات زين بين

$$
\text { الحقوقية، بيروت، } 2009 .
$$

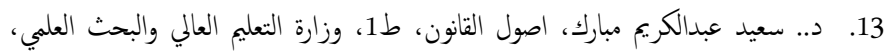

قد يواجه القاضي الوطني في بعض قواعد الاسناد عوقا ذاتيا يتعذر معه الوصول الى القانون واجب التطبيق كما في قاعدتي الانتزامات التعاقدية وغير التعاقدية، وعادة ما يكون الحل هو تطبيق قانون المحكة، فالذي يجلب الاختصاص التشريعي لقانون المحكة في مثل هذه الحالات هو الاختصاص

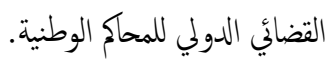

قد تشير احيانا قاعدة الاسناد المى اختصاص قانون اجنبي، ولكن يعجز القاضي رزغ تعاون الاطراف في الدعوى عن اثبات مضمون ذلك القانون الاجنبي، ولكي لا تبقى العلاقة دون قانون ينظمها ويككم نزاعاتها يكون البديل في هذه الحالة اللجوء الى قانون المحكة، فالذي يجلب الاختصاص التشريعي لقانون المحكة في حال تعذر اثبات القانون الاجنبي هو الاختصاص القضائي الدولي المحاكم الوطنية.

نوصي المشرع العراقي بتوسيع الاستثناء الوارد على القانون واجب التطبيق على التكييف، ليشمل بالاضافة الى اخضاع كون الشيء منقولا او عقارا لقانون محل وجوده اخضاع تكييف الوقائع المادية لقانون محل حدوثها، لان في ذلك موازنة بين اختصاص قانون القاضي والقانون الاجنبي في تكييف العلاقات الخاصة الدولية. نهبب بالمشرع العراقي تحديث قواعد تنازع القوانين العراقية، على نو يعاج مواطن العوق الذاتي في بعض القواعد والتي يتعذر معها الوصول للقانون واجب التطبيق في بعض الحالات، لكي تبقى العلاقات الخاصة الدولية محكومة بالقانون الاكثر صلة بها وفت قواعد تنازع القوانين. نوصي القاضي العراقي عند النظر في منازعات القانون الدولي الخاص الوقوف على الحياد في الموازنة بين قانونه الوطني والقانون الاجنبي وان لا يميل كثيرا الى تطبيق القانون الوطني الا في الحالات التي يعقد له فيها الاختصاص وفق قواعد الاسناد الوطنية او في الحالات التي يتعذر فها الوصول للقانون الاجنبي واجب التطبيق، وكل ذلك لاجل ان تحكى العلاقة القانونية باكثر القوانين ملائمة وعدالة وفق نظريات تنازع القوانين. 


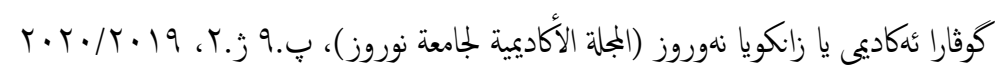

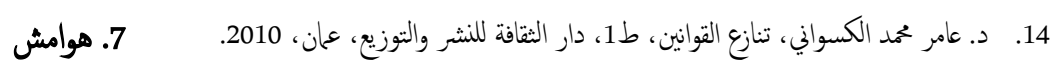

(1) ينظر في ذلك د. عزالدين عبداله، القانون الدولي الخاص، طو، ج2، الهيئة المصرية العامة

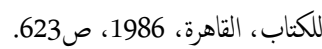

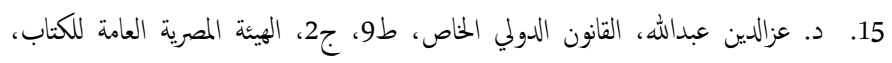

القاهرة، 1986.

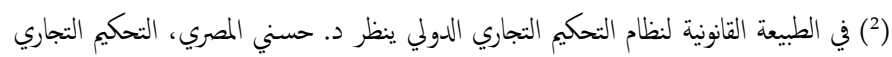

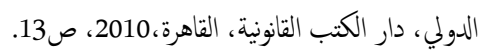

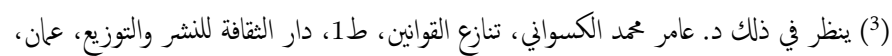

2010، صنا.73.

(4) د. ساي بديع منصور و د. اسامة العجوز، القانون الدولي الخاص، ط3، منشورات زين

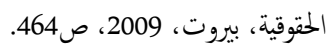

(5) ينظرالمادتين (14-15) من القانون المدني العراقي رقّ (404) لعام لعام 1951.

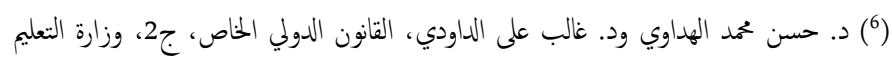

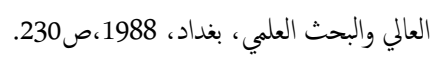

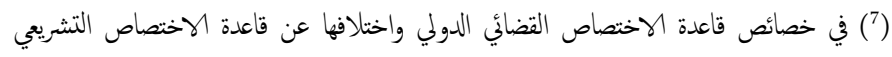

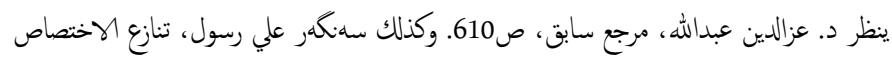

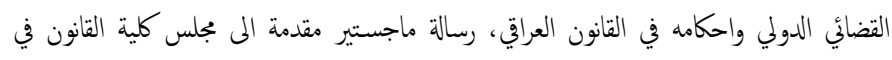

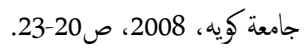

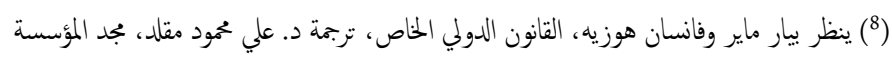

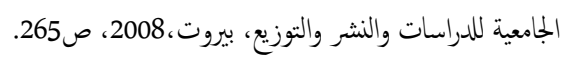

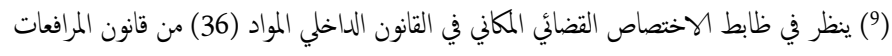

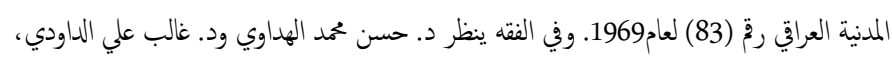

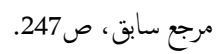

(10) (10) للمزيد من التفاصيل راجع المرجع نفسه، ص247.

(11) ينظر المادة (37) من قانون المرافعات المدنية العراقي.

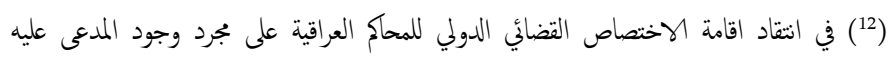

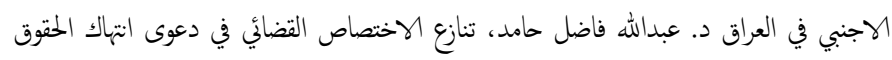

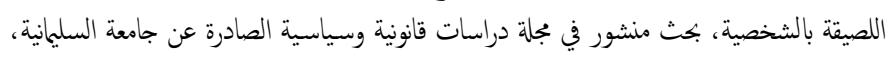

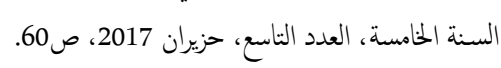

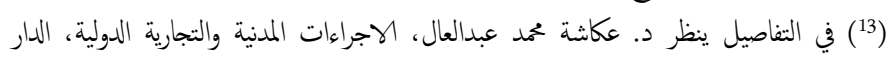

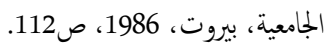

(14) ينظر د. امد عبدالكريم سلامة، القانون الدولي الخاص الماماراتي، مطبوعات جامعة الحمارات

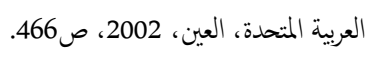

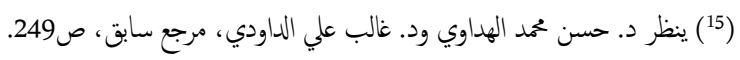

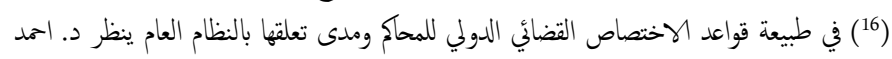

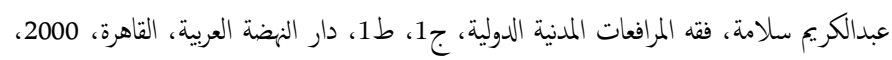

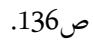

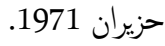

(17) ينظر في ذلك سهنكهر علي رسول، مرجع سابق، ص23.

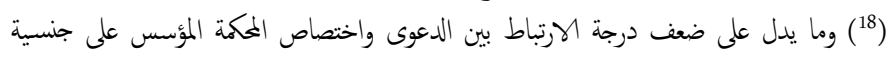

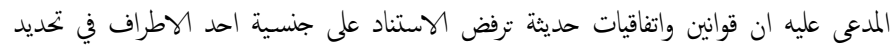

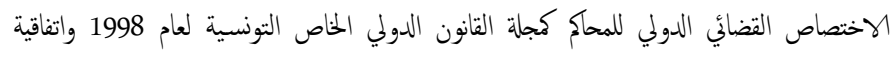

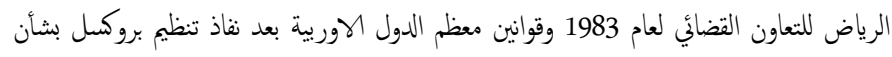

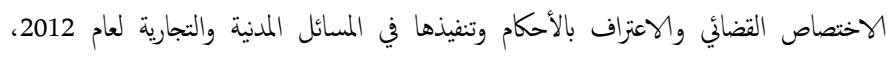

16. د. عكاشة محمد عبدالعال، الاجراءات المدنية والتجارية الدولية، الدار الجامعية، بيروت،

.1986

17. د. محمد وليد خالد، الوجيز في شرح القانون الدولي الخاص، دار الثقافة للنشر والتوزيع،

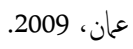

18. د. هشام علي صادق، دروس في القانون الدولي الخاص، الكناب الثاني، تنازع القوانين، دار

المطبوعات الجامعية، الاسكندرية، 2004.

19. د. هشام علي صادق، المطول في القنانون الدولي الخاص، ط1، ج1، تنانع القوانين،دار الفكر الجامعي، الاسكندرية، 2014.

2.6 البحوث والرسائل الجامعية

1. خليل ابراهيم محمد خليل، تكامل مناجه تنازع القوانين، اطروحة دكتوراه مقدمة

الى مجلس كلية الحقوق في جامعة الموصل، 2012.

2. سهنكةر علي رسول، تنازع الاختصاص القضائي الدولي واحكمه في القانون

العراقي، رسالة ماجستير مقدمة المى مجلس كلية القانون في جامعة كويه، 2008.

3. د. عبدالله فاضل حامد، تنازع الاختصاص القضائي في دعوى انتهاك الحقوق

اللصيقة بالشخصية، بحث منشور في مجلة دراسات قانونية وسياسية الصادرة

عن جامعة السليلينة، السنة الخامسة، العدد الناسع، حزيران 2017.

4. د. عبدالله فاضل حامد، تنازع القوانين في انتهاكات حقوق الشخصية عبر

وسائل الاعلام، بحث منشور في مجلة رسالة الحقوق الصادرة عن كلية القانون في جامعة كبلاء، السنة التاسعة، العدد الثالث، 2017.

5. د. ممدوح عبدالكريم حافظ، مبدأ النظام العام وتنازع القوانين، بحث منشور في

ججلة القانون والاقتصاد الصادرة في جامعة البصرة، العدد الخامس، البصرة،

5

3.6

3.
3.
3.




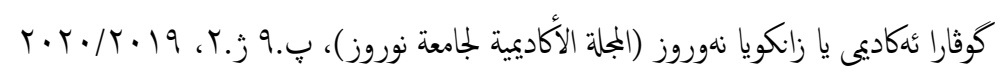

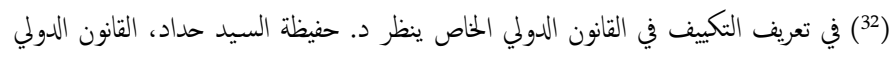

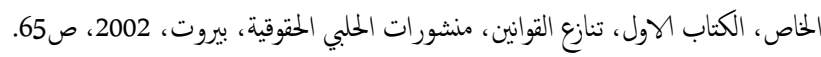

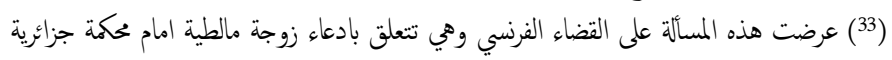

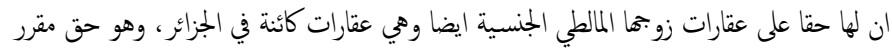

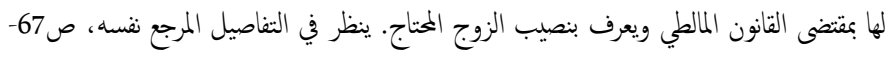

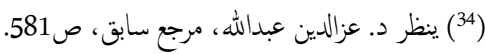

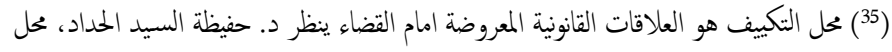

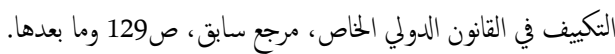

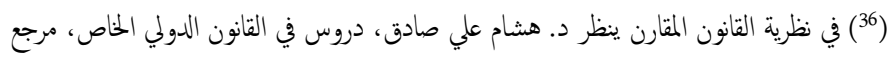

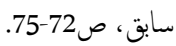
(37) في هذه النظرية ينظر د. حسن الهداوي، تنازع القوانين واحكامه في القانون الدولي الخاص

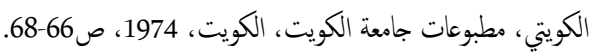

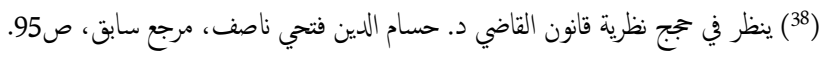

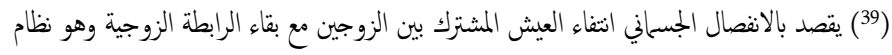
معمول به في القوانين الغربية.

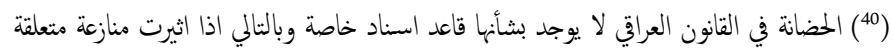

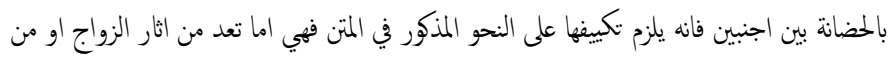

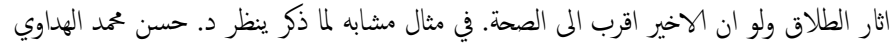

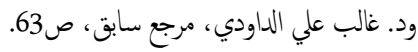

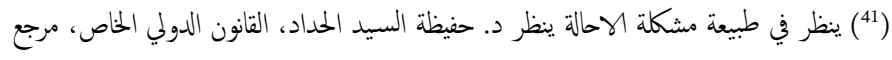

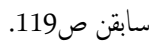
(42) في قضية قضائية ماثاثلة ملما مذور في المتن امام القضاء العراقي ينظر د. حسن محمد الهداوي ود.

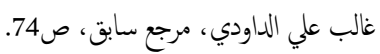

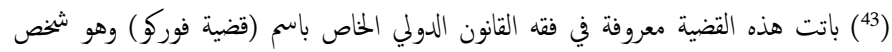

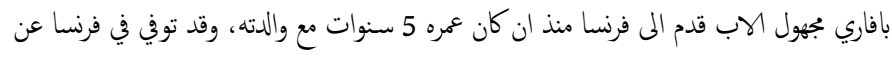

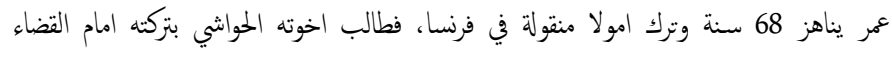

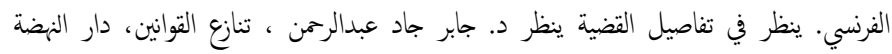

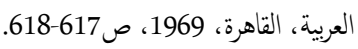

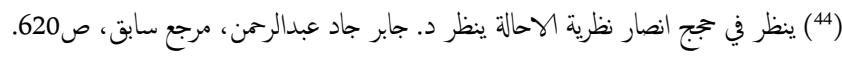

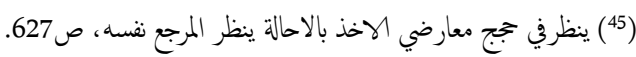

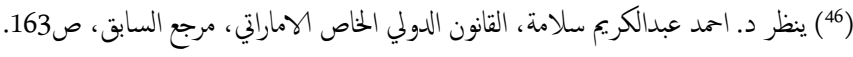

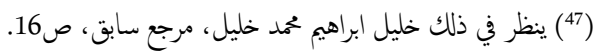

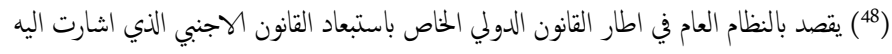

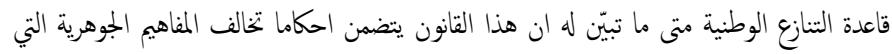

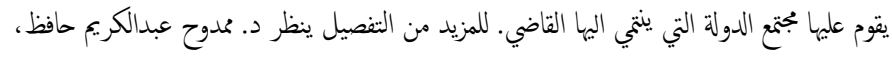

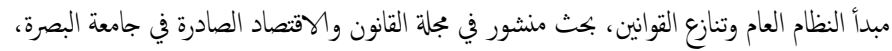

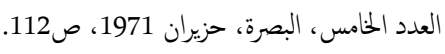

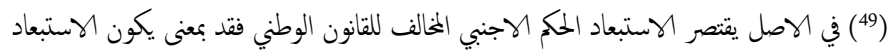

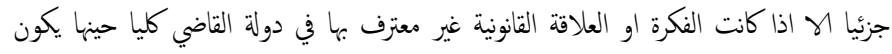

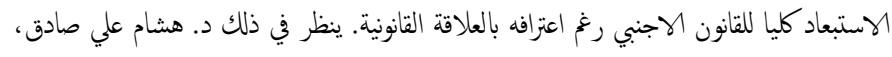

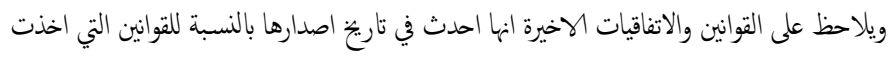

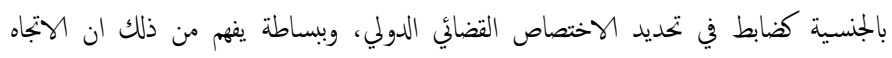

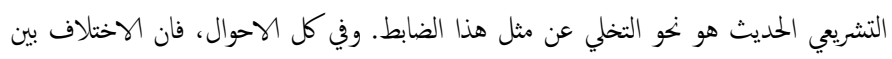

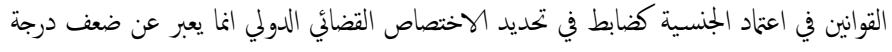

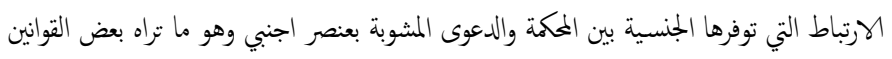

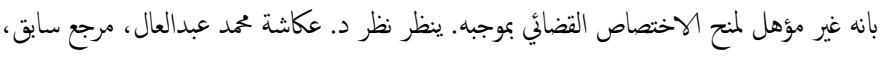

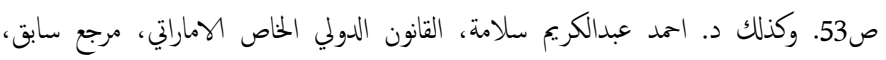

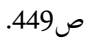
(19) د. عزالدين عبدالله، مرجع سابق، ص608. وكذلك د. حسن محمد الهداوي ود. غالب علي

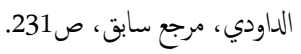

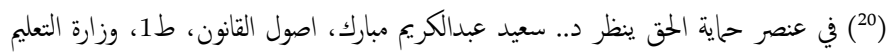

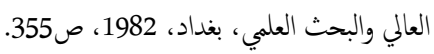

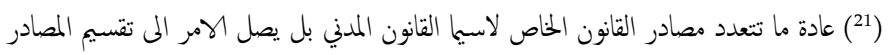

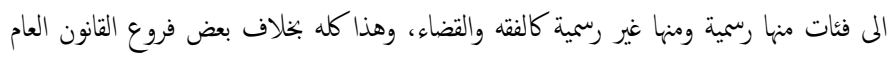

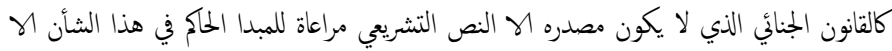
وهو مبدأ (لا جريمة ولا عقوبة اللا بنص)).

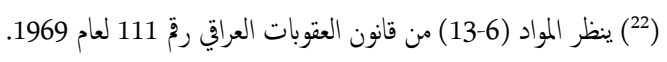

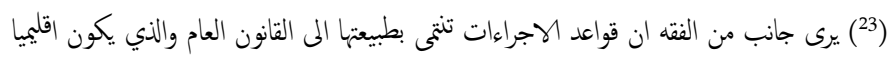

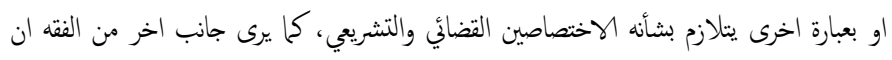

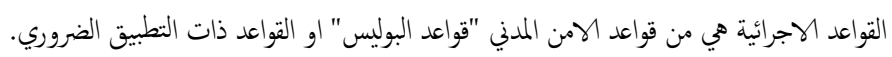

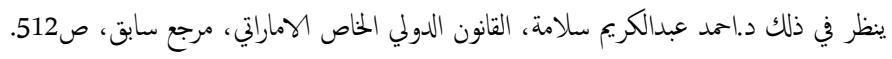

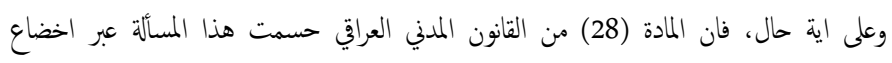

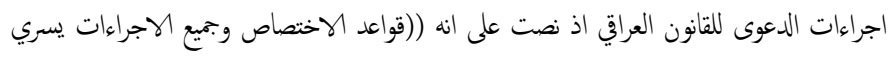

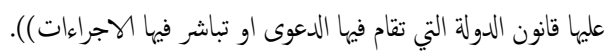

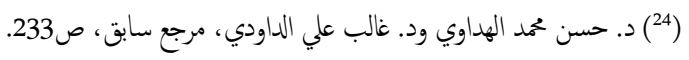
(25) ينظر المادة (31) من القانون المدني العراقي.

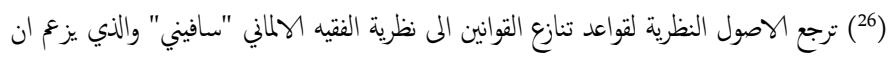

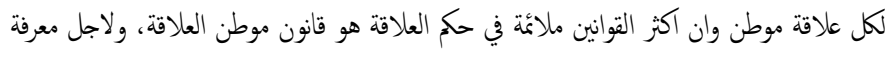

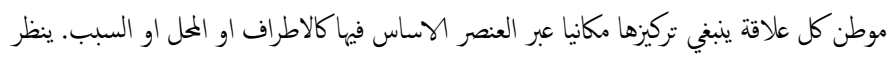

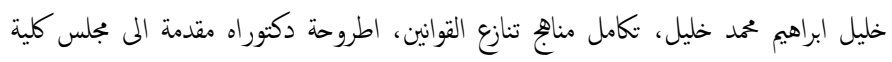

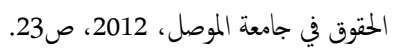
(27) ينظر د. هشام علي صادق، دروس في القان المانون الدولي الخاص، الكتاب الثاني، تنازع القوانين،

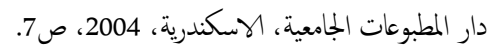

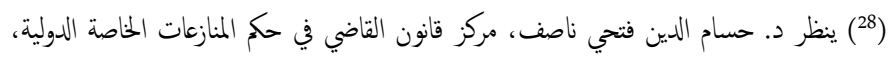

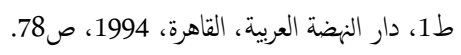

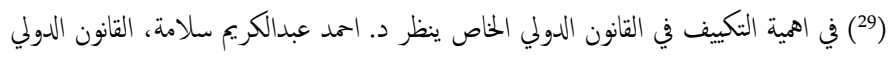

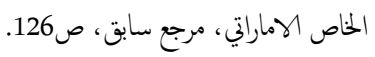
(30) ينظر د. حفيظة السيد الحداد، محل التكييف في القانون الدولي الخاص، منشأة المعارف، صوان،

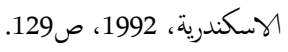

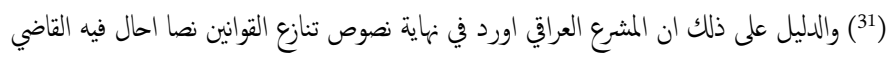

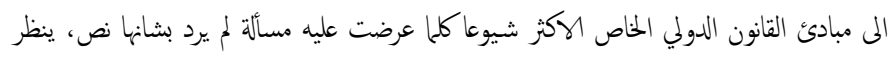
نص المادة (30) من القنانون المدني العراقي. 


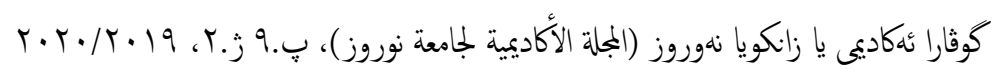

المطول في القانون الدولي الخاص، ط1، ج1، تنازع القوانين،دار الفكر الجامعي، الهسكندرية، 2014، ص440.

$$
\text { (50) ينظر حسام الدين فتحي ناصف، مرجع سابق، ص499. }
$$

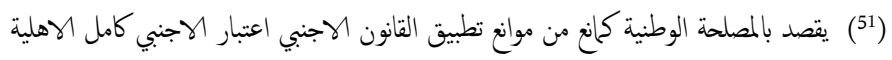

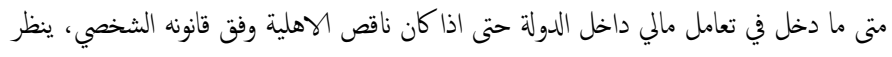

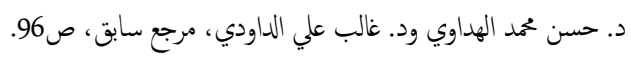

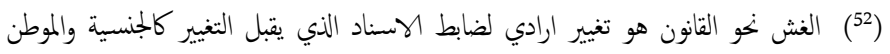

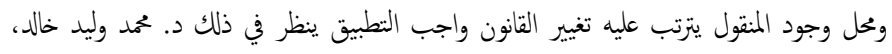

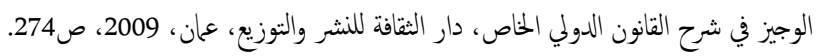

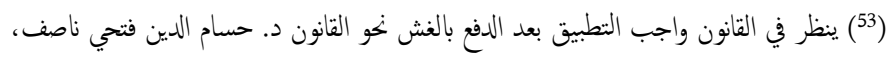

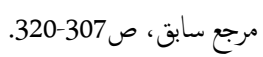

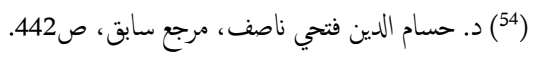

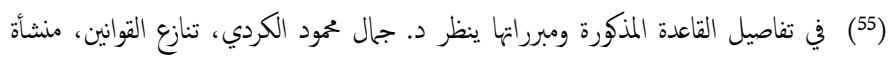

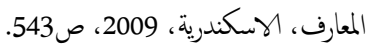
(56) ينظر د. حسن محمد الهداوي ود. غالب علي الداودي، مرجع سابق، ص153.

(57) تنص المادة (87) من القانون المدني العراقي على انه (1- يعتبر التعاقد ما بين الغائبين قد تم في الماني

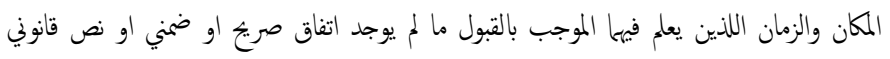

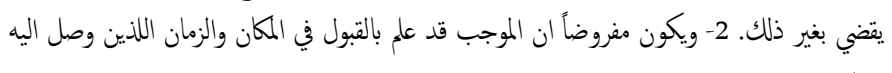

(58) ينظر في تفسير كلمة (الواقعة) في المادة 27 د. حسن محمد الهداوي ود. غالب علي الداودي، مرجع سابق، ص161. (59) ينظر د. د. عبدالله فاضل حامد، تنازع القوانين في انتهاكت حقوق الشخصية عبر وسائل

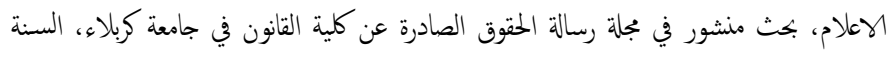

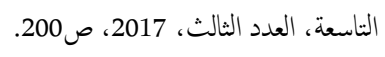

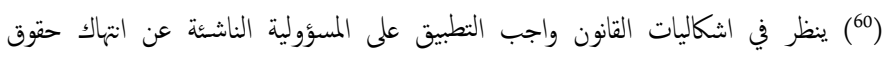

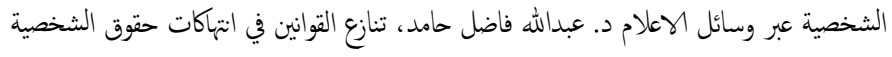

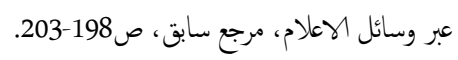
(230) ينظر في طبيعة القانون الاجنبي امام القضاء الوطني د. محمد وليد خالد، مرجع سابق، ص230. (22) ينظر في اثبات القانون الاجنبي عبر مصنفات الكاديمة امام القضاء الفرنسي د. هشام علي

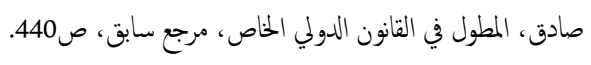

